\title{
Regression Analysis of the Effects of Habitability Laws Upon Rent: An Empirical Observation on the Ackerman-Komesar Debate
}

\author{
Werner Z. Hirsch ${ }^{\dagger}$ Joel G. Hirscht† \\ Stephen Margolis iti
}

In recent years there has been a debate concerning the economic wisdom of the recent proliferation of habitability laws. Unlike many debates in the law, the question whether the costs imposed upon landlords by such laws will be passed on to low-income tenants is capable of empirical resolution. This Article attempts to apply economic and statistical techniques to examine the effects of habitability laws upon rent. An economic model was constructed for urban rental housing markets. The rent impact of repair and deduct, rent withholding, receivership, and retaliatory eviction laws was then assessed with the aid of multiple regression techniques. Receivership laws were found to be associated with statistically significant higher rents. The analysis also revealed a positive, but not statistically significant, relationship between the presence of other habitability laws and rent levels. The Article concludes with a discussion of possible implications of these findings.

We cannot expect judges to solve the housing dilemma, but at least they should avoid affirmative action which makes it worse.

In 1949, Congress called for the realization as soon as feasible of the goal of a "decent home and suitable living environment for every

$\dagger$ Professor of Economics, University of California, Los Angeles; B.S. 1947, University of California, Berkeley; Ph.D. 1949, University of California, Berkeley.

ti A.B. 1973, University of California, Los Angeles; third-year student, Boalt Hall School of Law.

tif B.A. 1972, Northwestern University; M.A. 1973, University of Californin, Los Angeles.

Parts of the research conducted in preparing this article were made possible through a grant froin the Department of Housing and Urban Development (H-2232-R). The views expressed herein are those of the Authors and not those of HUD.

* Robinson v. Diamond Housing Corp., 463 F.2d 853, 871 (D.C. Cir. 1972). 
American family." However, significant barriers, such as the low income of many inhabitants of substandard dwellings, ${ }^{2}$ have precluded attainment of this goal..$^{3}$ Courts and legislatures have responded to the housing crisis by creating and extending the rights of residential tenants. The traditional landlord-tenant relationship, which was weighted heavily in favor of the landlord, has been modified to guarantee at least a minimum level of housing quality to tenants. Repair and deduct, rent withholding and abatement, receivership, and retaliatory eviction statutes have been passed in many states, and courts have increasingly implied a warranty of habitability into urban residential leases. ${ }^{4}$ It must be recognized, however, that these measures place burdens on landlords in the form of increased maintenance and operating costs, taxes, insurance, and risks of litigation. Depending on housing market demand and supply conditions, landlords may respond to such increased costs in three basic ways or combinations thereof: (1) absorb the costs and operate at a lower profit; (2) pass on the costs in the form of higher rents; or (3) abandon the building. ${ }^{5}$ Both the second and third modes

1. Housing Act of $1949 \S 2,63$ Stat. 413, as amended, 42 U.S.C. $\$ 1441$ (Supp. V, 1970).

2. See F.S. Kristof, Urban Housing Needs Through The 1980's, Research Report No. 10, National Commission on Urban Problems 61-63 (1968).

3. Due to a change in methodology, the Census Bureau no louger estimates substandard housing levels. However, it can be estimated that approximately one-eighth of America's 68 million housmg units were substandard or overcrowded in 1970. This estimate is based on the fact that 8.5 million units lacked "essential" plunbing facilities or were so crowded that the unit averaged more than one person per room. U.S. DEPARTment of Commerce, 1970 Census of Housing, Metropolitan Housing CharacterisTICS, FINAL RePORT HC(2)-1, Table A-1 (1972).

4. Within the last 14 years the highest courts of twelve jurisdictions have implied a warranty of habitability in urban residential leases: Wisconsin-Pines v. Perssion, 14 Wis. 2d 590, 111 N.W.2d 409 (1961), but cf., Posnanski v. Hood, 46 Wis. 2d 172, 174 N.W.2d 528 (1970); Hawaii-Lemle v. Breeden, 51 Hawaii 426, 462 P.2d 470 (1969); District of Columbia-Javins v. First Nat'l Realty Corp., 428 F.2d 1071 (D.C. Cir.), cert. denied, 400 U.S. 925 (1970); New Jersey-Marini v. Ireland, 56 N.J. 130, 265 A.2d 526 (1970) (only repair and deduct remedy allowed); New Hampshire-Kline v. Burns, 111 N.H. 87, 276 A.2d 248 (1971); Illinois-Jack Spring, Inc. v. Little, $50 \mathrm{nI}$. 2d 351, 280 N.E.2d 208 (1972); Iowa-Mease v. Fox, 200 N.W.2d 791 (1972); Massachusetts-Boston Housing Authority v. Hemingway, - Mass. -, 293 N.E.2d 831 (1973); Washington-Foisy v. Wyman, 83 Wasl. 2d 22, 515 P.2d 160 (1973); Minuesota-Fritz v. Warthen, 298 Minn. 54, 213 N.W.2d 339 (1973); Kansas-Steele v. Latimore, 214 Kan. 329, 521 P.2d 304 (1974); California-Green v. Superior Court, 10 Cal. 3d 616, 517 P.2d 1168, 111 Cal. Rptr. 704 (1974).

Tentative Draft Number 2 of the RESTATEMENT (SECOND) of Property adopts the warranty of habitability doctrine by providing for repair and deduct and rent withholding reniedies. See Restatement (Second) of Property $\$ 5.1$ (Tent. Draft No. 2, 1974). See generally Meyers, The Covenant of Habitability and the American Law Institute, 27 STAN. L. REv. 879 (1975).

5. Soine landlords might also be able to sell their buildings. This mode of response is infrequent because most of the buildings with major housing code violations have hittle marketability. 
of action are detrimental to low-incorne tenants. The possibility thus exists that the class of persons deemed by legislatures and courts to be best able to bear the costs-landlords-may often pass on the increased costs of maintaining habitable living quarters to the class of personslow-income tenants-deemed least able to bear the burden. ${ }^{\circ}$

Legislators and judges have often failed to consider this danger. In one of the few decisions to consider the issue explicitly, Robinson v. Diamond Housing Corp., ${ }^{7}$ Judge Skelly Wright reasoned:

Of course, if the housing inarket is structured in such a way that it is impossible for landlords to absorb the cost of bringing their units into compliance with the code, there inay be nothing a court can do to prevent vigorous housing code enforcenent from driving low cost housing off the inarket. But the nrost recent scholarship on the subject indicates this danger is largely imagined. In fact, it appears that vigorous code enforceinent plays little or no role in the decrease in low cost housing stock. When code enforcement is seriously pursued, market forces generally prevent landlords from passing on their increased costs through rent increases. See generally Ackerman, Regulating Slum Housing Markets on Behalf of the Poor: Of Housing Codes, Housing Subsidies, and Income Redistribution Policy, 80 Yale L.J. 1093 (1971).8

However, the Ackerman article cited in Robinson was an entirely theoretical piece which offered no empirical evidence to support the liypotheticals presented..$^{0}$ Professor Komesar, a lawyer-economist, inade the following comment on the Ackerman article:

Such a conception of the housing market may be substantially erroneous and the effects of decisions based upon this conception may differ materially from those expected. It is important that the legal community be aware that not all 'recent scholarship' [referring to the Robinson decision] can portray so manageable a housing market. ${ }^{10}$

6. This may result from the fundamental economic maxim that there is no such thing as a "free lunch." The rule, however, is not absolute. There are situations in which the court's allocation of rights can redistribute wealth. A prime example is a long term contractual relationship. If a tenant has a long term lease with a specified monthly rent, the lease agreement will usually prevent the landlord from raising the rent in response to the intervening passage of a law which requires the landlord to improve the tenant's premises. In such a situation it can be said that in the short run the tenant has received a "free" benefit. The vast majority of low-income tenants, however, lease their dwellings on a month-to-month, tenancy-at-will basis and thus are extremely susceptible to fluctuations in price. Consequently, the low-income tenants are unlikely to receive many "free" benefits of this sort.

7. 463 F.2d 853 (D.C. Cir. 1972).

8. Id. at 860 (emphasis added; footnote omitted).

9. Ackerman, Regulating Slum Housing Markets on Behalf of the Poor: Of Housing Code Enforcement and the Poor, 80 YALE L.J. 1093 (1971) [hereinafter citcd as Ackerman, Slum Housing Markets].

10. Komesar, Return to Slumville-A Critique of the Ackerman Analysls of 
The question whether costs of inaintaining habitable housing will be passed on to low-income tenants is capable of empirical resolution. It is the purpose of this Article to evaluate the likely rent effect of code enforcement. There are two aspects to this inquiry: (1) Will vigorous housing code enforcement lead to any increases in rent? (2) If such enforcement does indeed lead to rent increases, are the rent increases smaller than the accompanying benefits obtained by low-income tenants? Both formulations pose the possibility that the expansion of tenant rights inay in fact hurt, rather than help, low-income tenants.

This Article will mainly concern itself with the first level of the Ackerman-Komesar debate-the rent effect-and toward the end briefly consider the second question, admittedly the more significant and the more difficult. Part I briefly summarizes the various tenant-initiated remedies now existing in numerous jurisdictions. Part II offers an economic nodel of the landlord's response to such laws. Part III presents the results of an empirical examination conducted to determine

Housing Code Enforcement and the Poor, 82 YALE L.J. 1175, 1187 (1973) [hereinafter cited as Komesar, Critique]. But see Ackerman, More on Slum Housing and Redistribution Policy: A Reply to Professor Komesar, 82 YALE L.J. 1194 (1973).

Richard Posner evaluated the merits of the respective positions in the AckermanKomesar debate and concluded that strict housing code enforcement would indeed result in higher rentals and curtailment of the housing supply for low-income tenants. Posner also argued that the same analysis would apply to the use of tenant self-help remedies such as rent withholding under a warranty of habitability. R. POSNER, EcONOMIC ANALYSIS of LAW 259-62 (1973). Posner recognized that in the absence of government subsidies the costs that result from housing code enforcement must come either from "the rentals paid by tenants or the rent of land obtained by the landlords." Id. at 260. He concludes, without empirical documentation, that "tenants forced to pay higher rentals to cover the cost of compliance . . . will be made worse off." Id. The extent of the tenant's detriment depends in part on how the costs of compliance are distributed between landlord and tenant. The nature of this cost allocation can be analyzed with the aid of such economic concepts as demand and supply elasticities of rental housing. See section B of part II infra.

Other commentators have similarly reached opposing conclusions as to the allocation of costs between landlord and teuant. One commentator has questioned the likelihood of rent increases on the ground that landlords are financially capable of absorbing the increased costs. Comment, Rent Withholding and the Improvement of Substandard Housing, 53 CALIF. L. Rev. 304, 320-22 n.83 (1965). As will later be shown, the profitability of slumlordism is not the determinative factor; there is no reason to suspect that wealthy slumlords will voluntarily absorb the increased costs unless prevailing supply and demand conditions force them to do so. See text accompanying notes 76-81 infra.

Others have concluded that such increased costs will probably be passed on to tenants. Meyers, The Covenant of Habitability and the American Law Institute, 27 STAN. L. Rev. 879, 893 (1975); Sax \& Hiestand, Slumlordism as a Tort, 65 MrcH. L. Rev. 869, 873-74 (1967); Note, Landlord's Violation of Housing Code During Lease Term is Breach of Implied Warranty of Habitability Constituting Partial or Total Defense to an Eviction Action Based on Nonpayment of Rent, 84 HARV. L. Rev. 729, 733-36 (1971); Comment, Rent Withholding Won't Work: The Need for a Realistic Rehabilitation Policy, 7 Loy. (L.A.) L. REv. 66, 83 (1974). 
whether and, if so, how much of the increased costs associated with minimum housing quality laws have been passed on to low-income tenants in the form of higher rents. Part IV discusses conclusions drawn from these empirical findings and presents soune policy implications.

\section{I \\ MODIFICATIONS OF THE \\ Traditional LANDLORD-TENANT ReLationship}

\section{A. Historical Setting}

Until recently, most American states retained the common law rule that landlords owe no duty to deliver and maintain residential premises in a habitable condition. ${ }^{11}$ A lease at common law was considered a conveyance of property for a term, and subject to the doctrine of caveat emptor; ${ }^{12}$ thus the tenant was deemed to have assumed the obligations and liabilities of ownership. ${ }^{13}$ Further, since the rules of property law sohdified before the development of mutually dependent covenants in contract law, a lessee's covenant to pay rent was considered independent of the lessor's covenants. ${ }^{14}$ Thus even if a landlord covenanted to maintain the premises, a breach did not relieve the tenant of liability for rent. ${ }^{15}$

11. Divines v. Dickson, 189 Iowa I94, 174 N.W. 8 (1919); Lyon v. Buerman, 70 N.J. 620, 57 A. 1009 (1904); Gallagher v. Button, 73 Conn. 172, 46 A. 819 (1900).

12. See Restatement (SECOND) of TORTS \& 356, comment $a$ at 240 (1963); Lawler v. Capital City Life Ins. Co., 68 F.2d 438 (D.C. Cir. 1933); Fowler v. Bott, 6 Mass. 63 (1809); Warner v. Fry, 360 Mo. 496, 228 S.W.2d 729 (1950).

13. 1 AMERICAN LaW of Property $\$ 3.38$ (A.J. Casner ed. 1952).

14. Restatement of Contracts $\$ 290$ (1932). The rnle of dependent covenants has prevailed in contract law since Boone v. Eyre, 126 Eng. Rep. 160 (House of Lords 1777).

15. Fowler v. Bott, 6 Mass. 63 (1809). A number of states have for many years possessed statutory and case law exceptions to the traditional common law rule. Louisiana, with its civil law tradition, had a repair and deduct exception to the traditional "no-repair" rule at an early date. See LA. C.C. CoMP. ED. art. 2693 and 2694, in 17 L.S.A.C.C. (West 1972). Other examples of statutes enacted at an early date include CAL. CTV. CODE $\$ \$ 1941-42$ (West 1954); REv. CODE. MONT. ANN. \$\$ $42-201$ and -202 (Smith 1961); N.D. CENT. CODE \$§ 47-16-12 and -13 (Smith 1960); S.D. CoMP. LAWS ANN. \$§ 43-32-8 and -9 (Smith 1967). Further, Georgia had the foundation for a withholding remedy as early as 1900, see Stack v. Harris, 111 Ga. 149 (1900), and for a repair and deduct remedy as early as 1909 , see Doughterty v. Taylor \& Norton Co., 5 Ga. App. 773, 63 S.E. 928 (1909).

The following statutes require the landlord to put leased residential premises into a condition fit for human habitation and give the tenant the right to terminate if the landlord fails to comply: California-CAL. Crv. CoDe $\$ \$ 1932,1941$ (West 1954), $\S \S 1941.1,1942,1942.1$ (West Supp. 1975); Connecticut-Conn. Gen. Stat. ANN. \& 47-24a (1949); $\$ 47-24 b$ (Supp. 1975); Delaware-DEL. CODE ANN. tit. 25, §§ 5111 (3), (5) (Supp. 1974); District of Columbia-D.C. Housing Code $\$ \$ 2902.1,2902.2$ (1972); Georgia-GA. CODE ANN. \$ 61-111 (1962) (not limited to residential leases); Louisiana-LA. Crv. CoDE ANN. art. 2692, 2693, 2695, 2729 (West 1952) (not limited to residential leases); Maine-ME. Rev. Stat. ANN. tit. 14, § 6021 (Supp. 1974); Mas- 
The common law landlord-tenant relationship was significantly modified by the passage of housing codes by most American cities in the years following World War $\Pi 1 .{ }^{16}$ Generally, these codes imposed responsibility on the landlord for inost repair and maintenance, ${ }^{17}$ even when the housing code violation was caused by the tenant. ${ }^{18}$ The tenant was obligated only to keep the dwelling clean, ${ }^{19}$ and to perform other narrowly-defined maintenance. ${ }^{20}$ While the precise standards utilized by housing codes vary, there would be little or no housing quality problem in this country if the housing stock conformed to legal standards. ${ }^{21}$ Nonetheless, the 1970 Census found that one-eighth of the nation's renters occupied living quarters which lacked some or all plumbing fa-

sachusetts-Mass. Gen. LAws ANN. ch. 111, § 127L (Supp. 1975); Michigan-Mich. COMP. LAws ANN. $\$ 554.139$ (Supp. 1975) (no specific right to terminate); MontanaMoNT. Rev. CODES ANN. \$\$ 42-201, 42-202, 42-108 (1961); New York-N.Y. Multr. DWELL. LAW $\$$ 78, 80 (McKinney 1946); MULTI. REST. LAW $\$ 174$ (McKinney 1952) (no specific right to terminate); North Dakota-N.D. CeNT. CoDE $\$ \S 47-16-12$, 47-1613, 47-16-17 (1960); Oklahoma-OKLA. STAT. ANN. tit. 41, §§ 31, 32 (1954); Rhode Island-R.I. GEN. LAWS ANN. § 34-18-16 (1969) (no specific right to terminate); South Dakota-S.D. CoMP. LAws ANN. \$§ 43-32-8, 43-32-9, 43-32-19 (1967).

In addition to statutory exceptions, there are two longstanding doctrinal exceptions to the common law rule. The doctrine of constructive eviction excuses future payinents of rent when the landlord has allowed the premises to deteriorate to such an extent that the resulting conditions interfere with the tenant's enjoyment of the leasehold. The tenant, however, must vacate the premises within a reasonable time in order to invoke the benefits of the doctrine. E.g., Dyett v. Pendleton, 8 Cow. 727 (N.Y. 1826); Rapacz, Origin and Evolution of Constructive Eviction in the United States, 1 DE PAUL L. REv. 69 (1951). Given the tight supply of low priced housing and the high costs and disruptive effects of inoving, constructive eviction is an unrealistic remedy for the low-incoine tenant. See Note, Enforcement of Municipal Housing Codes, 78 HARv. L. Rev. 801,844 (1965). A tenant would save one month's rent by invoking the doctrine and vacating the premises, a saving which is unlikely to offset the costs and inconvenience involved in relocation.

The second longstanding nonstatutory exception to the no-repair rule, the doctrine of partial eviction, is also of httle utility to the low-incone tenant. This doctrine relieves a tenant deprived of a portion of the premises froin paying rent until he regains access to the entire leasehold. E.g., Fifth Ave. Bldg. Co. v. Kernochan, 221 N.Y. 370, 117 N.E. 579 (1917) (Cardozo, J.). However, the doctrime is limited to ouster resulting from a physical act of the landlord. Courts have strictly interpreted the doctrine to exclude situations involving constructive eviction from only a portion of the premises. E.g., Gombo v. Martise, 41 Mise. 2d 475, 246 N.Y.S.2d 750 (N.Y.C. Civ. Ct.), rev'd on other grounds, 44 Misc. $2 \mathrm{~d}$ 239, 253 N.Y.S.2d 459 (Sup. Ct. 1964).

16. See generally Note, Municipal Housing Codes, 69 HARv. L. Rev. 1115 (1956).

17. In relation to repairs, see, e.g., Iowa CoDE ANN. $\$ 413.66$ (1949); MicH. Comp. LAws ANN. $\$ 125.471$ (1967). In relation to maintenance, see, e.g., Iowa CoDE ANN. \& 413.69 (1949); MASs. GeN. ANn. LAws ch. 144 \& 66 (1968).

18. E.g., N.Y. MULT1. Dwell. LAW $\$ 78.80$ (MCKinney 1974).

19. E.g., Minn. Stat. ANN. $\$ 460.55$ (1963).

20. For exainple, hanging of window screens, the maintenance of self-closing doors, the unblocking of fire escapes, the removal of obstructions in hallways, the reinoval of garbage, and the proper care of appliances. NEW YoRK CrTY HousIng MAINTENANCE CODE § D26.10.05 (1967).

21. R. POSNER, ECONOMIC ANAIYSIS OF LAW 259 (1972). 
cilities or were severely overcrowded; either condition would violate even the least restrictive housing codes. ${ }^{22}$

The problem, then, is not the absence of laws, but rather that existing laws are not being enforced. The general lack of strict housing code enforcement has been attributed to a number of well documented factors: inadequate minimum penalties for violations, lack of competent personnel, insufficient appropriations to administrative enforcement departments, and lax judicial enforcement. ${ }^{23}$ It has also been suggested, however, that the lack of effective housing code enforcement is attributable to the fear of policymakers that strict enforcement would be counterproductive. ${ }^{24}$ It is asserted that government officials responsible for code enforcement are concerned that the costs of requiring landlords to bring their property to code standards would force landlords to increase their rents or abandon their buildings, thereby depriving lowincome tenants of even substandard housing. ${ }^{25}$

\section{B. Recent Developments}

Courts and legislatures have responded to the lack of strict housing code enforcement and the consequent persistence of substandard housing by allowing tenants to initiate code enforcement. These remedies are generally of three types: (1) repair and deduct; (2) rent withholding; and (3) receivership. The cost of these remedies to the landlord depends upon the nature of the rights extended to tenants, the ease with which tenants can exercise their rights, and the level of physical standards incorporated into such remedies.

\section{Repair and Deduct}

The repair and deduct reinedy allows the tenant to subtract from the rent the cost of repairing defective premises if the landlord fails to remedy the defect after notice. Of the twenty jurisdictions which have adopted repair and deduct remedies, ${ }^{26}$ approximately one-half allow the

22. U.S. Department of Commerce, 1970 Census of Housing, Metropolitan Housing Characteristics, Final Report HC(2)-1, Table 1-A (1972).

23. See F. Grad, Legal Remedies for Housing Code Violations, National Commission on Urban Problems, Reszarch Report No. 14 (1968); Ford, The Enforcement of Housing Legislation, 42 PoL. Scr. Q. 549, 551-60 (1927); Gribetz \& Grad, Housing Code Enforcement: Sanctions and Remedies, 66 CoLuM. L. REv. 1254 (1966); Levi, Focal Leverage Points in Problems Relating to Real Property, 66 CoLUM. L. Rev. 275 (1966); Note, Enforcement of Municipal Housing Codes, 78 HARv. L. REv. 801 (1965); Note, Municipal Housing Codes, 69 HARv. L. REv. 1115 (1966).

24. Ackerman, Slum Housing Markets 1093-95.

25. Id. at 1095 .

26. Alaska-AIAs. Stat. tit. 34, $\$ 34.03 .180$ (Supp. 1974); Arizona-Aruz. Rev. Stat. tit. 33, § 1363 (1974); California-CaI. CIv. Code \$\$ 1941, 1942 (West 1959); Delaware-DEL. CODE ANN. tit. 25, $\$ \S 5306,5307$ (1974); Georgia-Doughtery 
tenant to deduct no more than one month's rent. ${ }^{27}$ Thus the remedy is usually limited to relatively minor defects unless used collectively by a number of tenants. Repair and deduct is also limited in some states by the landlord's ability to imsert a provision in the lease waiving the tenant's right to the remedy. ${ }^{28}$ As a result of these limitations, repair and deduct is the least costly to the landlord of the tenant-initiated code enforcement mechanisms.

The relatively shight costs to the landlord are balanced by the relative ease of invoking the reinedy, since no prior judicial determination is required. But as with virtually all tenant withholding remedies, the tenant runs the risk that a subsequent judicial proceeding will determine that the tenant was unjustified in taking action and has breached the lease agreement. ${ }^{29}$ Additionally, the existence of the repair and deduct remedy provides a basis for holding a tenant liable for

v. Taylor \& Norton Co., 5 Ga. App. 773, 63 S.E. 928 (1909); Hawaii-HaWAI Rev. Stat. \$ 521-64 (Supp. 1974); Kentucky-KY. Rev. Stat. \$ 383.635 (Supp. 1974) (per $\$ 383.715$, applicable to counties containing cities of the first class and urban-county governments); Louisiana-LA. Crv. CODE art. 2693-94 (West 1973); MassachusettsMass. Gen. Laws cli. 111, \& 127L (Supp. 1975); Michigan-Mrch. Comp. Laws ANN. $\S 125.534$ (Supp. 1974-75) (court may order rent application); Montana-REv. CoDE Mont. ANN. §§ 42-201 and -202 (1961); Nebraska-Rev. STAT. NEB. $\$ 76-1427$ (R.S. Cum. Supp. 1974) (limited to utilities or essential services); New Jersey-Marini v. Ireland, 56 N.J. 130, 265 A.2d 526 (1970); North Dakota-N.D. CENT. CoDE $\S \S 47-16-$ 12 and -13 (1960); Ohio-OHo REv. CODE $\S \S 1923.061,5321.07$ (Supp. 1974); Oklaloma-OkIa. Stat. ANN. tit. 41, §§ 31, 32 (1954); Oregon-Ore. Laws cl. 559, § 20 (1) (a) (1973) (limited to repair of utilities or essential services only); South DakotaS.D. COMP. LAWS \& 43-32-9 (1967); Virginia-VA. CODE ANN. \& 32-64-66 (1973) (toilet facilities only); Washington-REv. CODE OF WASH. ANN. tit. 59, ch. 18, \& 100 (Supp. 1973).

27. The following states, for example, limit the amount which a tenant may deduct: Delaware ( $\$ 50)$; Hawaii ( $\$ 100$ or a month's rent); Arizona ( $\$ 150$ or one-half of a month's rent, whichever is greater); California (one month's rent; can be invoked only once during a twelve month period); Massachusetts (two months' rent; can be invoked only once in a twelve month period or period of occupancy, whichever is shorter). No limit specified in Louisiana, North Dakota, Oklahoma, South Dakota.

28. A number of states expressly deny effect to exculpatory clauses. E.g., CaL. Civ. Code $\$ 1942.1$ (West Supp. 1975); Mass. GEN. Laws ch. 111, $\$ 127 \mathrm{~L}$ (Supp. 1975). But see MoNT. Rev. Code ANN. \$ 42-201 (1961); N.D. CENT. CODE § 47-1612 (1960); OkIA. STAT. ANN. tit. 41, § 31 (1951); S.D. Comp. LaWs $\$ 43-32-8$ (1967). In Louisiana the courts have construed this result into the statute. Pecararo v. Grover, 5 LA. APP. 676 (1927); and see LA. CTv. Code ANN. art. 11, $\$ 2693$ (West 1952) (allowing waiver of statutory protection by party if not against public policy).

29. Some statutory repair and deduct remedies provide the tenant with greater certainty than other withholding remedies by specifying the conditions under which a tenant may repair and deduct. See, e.g., CaL. Crv. CoDE $\$ 1941.1$ (West Supp. 1974). While such enumeration of conditions may reduce the tenant's risk of breaching the lease agreement by misjudging the "tenantability" or "habitability" of the premises, a great deal of interpretation and, hence, uncertainty remains. Any risk rednction froin such enumeration may be illusory since the conditions specified in the statute must still be interpreted in light of housing codes typically phrased in such general terms as "good working" or "sanitary" condition. 
any personal injuries resulting from the tenant's failure to repair defects. ${ }^{30}$

The repair and deduct remedy may be a relatively inefficient ineans of code enforcement. Especially in large inultiple unit dwellings, the landlord should be able to repair defects and maintain the premises inore efficiently than would a large number of individual tenants. Tenants contracting for repair probably have hittle experience in such dealings. Further, they have little incentive to seek economical methods of repair or the lowest bidders for a given repair. They would have little reason to inonitor the quality of the work to see that repairs would be long lasting, and they might tend to overlook more serious long-run problems in favor of cosmetic repairs where the two might efficiently be undertaken simultaneously. Finally, the tenant would be unable to coordinate any repairs with work done elsewhere in the building, or with the overall plans for building use. ${ }^{31}$

\section{Rent Withholding}

Twenty-eight jurisdictions allow tenants to withhold rent if the landlord fails to correct serious housing code violations. ${ }^{32}$ These rent

30. Sherrard v. Lidyoff, 108 Cal. App. 2d 325, 239 P.2d 28 (2d Dist. 1952); Nelson v. Meyers, 94 Cal. App. 66, 270 P. 719 (3d Dist. 1928).

31. However, the repair and deduct remedy might bo justified on the grounds that once the landlord has refused, repairs made by tenants may constitute the next best possible alternative.

32. Alaska-ALAs. Stat. tit. 34, $\S \S 34.03 .100,34.03 .180,34.03 .190,34.03 .210$ (Supp. 1974) (warranty of habitability and remedies); Arizona-ARuz. REV. STAT. \$ 33-1324 and -1365 (1974) (warranty of habitability and escrow); California-Green v. Superior Court, 10 Cal. 3d 616, 517 P.2d 1168, 111 Cal. Rptr. 704 (1974); Connecticut -Conn. Gen. Stat. ANn. \$§ 47-24b et seq. (Supp. 1974-75); Delaware-Der. Codz ANN. tit. 25, $\S 5101$ et seq. (1974); District of Columbia-Javins v. First Nat'l Realty Co., 428 F.2d 1071 (D.C. Cir. 1970), cert. denied, 400 U.S. 925 (1970); Florida-FLA. STAT. ANN. $\$ \S 83.51,83.60$ (Supp. 1975-76) (warranty of habitability and remedies); Georgia-GA. CODE ANN. \$\$ 61-111 and -112 (1935); Illinois-Jack Spring, Inc. v. Little, 50 I1.2d 351, 280 N.E.2d 208 (1972); Iowa-Mease v. Fox, 200 N.W.2d 791 (1972) and Iowa CODE ANN. $\$ 413.106$ (1949) (rent abatement); Kansas-Steelo v. Latimer, 521 P.2d 304 (1974); Kentucky-KY. Rev. STAT. \$\$ 383.595, 383.645 (Supp. 1974) (warranty of habitability and remedies); Maine-Me. Rev. STAT. tit. 14, $\$ 6021$ (Supp. 1974-75); Massachusetts-MAss. GeN. LAws ANN. ch. 239, \& 8A (Supp. 1975) and Boston Housing Authority v. Hemingway, 293 N.E.2d 831 (1973); MichiganMich. CoMp. LAws ANr. $\$ 554.139$ (Supp. 1975-76) (warranty of habitability) and Rome v. Walker, 38 Mich. App. 458, 196 N.W.2d 859 (1972); Minnesota-MinN. Stat. ANN. \& 504.18 (Supp. 1975-76) and Fritz v. Warther, 213 N.W.2d 339 (1973); Missouri -ANN. Mo. Stat. \& 441.570 (Supp. 1975) (requiring deposit of rent with clerk of the court) and King v. Moorehead, 495 S.W.2d 65 (1973); Nebraska-Rev. STaT. Ned. \$\$ 24-568, 76-1419, 76-1428 (Supp. 1974) (warranty of habitability and remedies); New Hampshire-Klino v. Burns, 111 N.H. 87, 276 A.2d 248 (1971); New Jersey-N.J. STAT. ANN. tit. 2A, \& 2A:42-92 (Supp. 1975-76) (escrow remedy); New York-N.Y. Real Prop. Act. \& Proc. \$ 755(2) (McKinney 1963) (applies only to New York City), 769 et seq. (McKinney Supp. 1974-75) (a rent strike authorized if one-third or 
withholding schemes can be conceptually divided into two classes in terms of their probable costs to landlords: escrow and abatement inethods.

\section{a. Escrow Method}

The escrow method of rent withholding, the exclusive remedy in some states, ${ }^{33}$ allows a tenant to pay rent into a court-created escrow, thereby depriving the landlord of rental income until the violations are corrected. $^{34}$ Upon satisfactory correction, the inoney, minus any administrative costs and authorized disbursements, ${ }^{35}$ is returned to the landlord.

Three states authorize by statute rent withholding by a state welfare department or similar agency whenever it is discovered that a recipient of public assistance is occupying housing which is in violation of housing or sanitary codes. ${ }^{36}$ As long as the violations continue, a welfare recipient has a statutory defense to any action or summary proceeding for nonpayment of rent. ${ }^{37}$ The rationale behind such statutes is that the state should not support landlords who violate the law. ${ }^{38}$

more of tenants in building petition court) and N.Y. MULTr. DwelL. LAW $\S \S 302 a$, 305a, 309 (McKinney Supp. 1974-75); Ohio-OHL Rev. CODE $\$ \S 1923.061,5321.04$ (Supp. 1974) (escrow remedy and warranty of habitability); Oregon-ORE. RRv. STAT. tit. 10 , ch. $91, \S \S 91.770, .800$ to .815 (1974) (warranty of habitability and remedies); Pennsylvania-PA. Stat. ANN. tit. 35, $\$ 1700-1$ (Supp. 197475); Tennessee-Tenn. CODE ANN. \$§ 53-5501 et seq. (Supp. 1974) (deposit of rent); Virginia-VA. CODE ANN. ch. 132, art. 4, $\$ \S 55-248.25$ et seq. (Supp. 1974) (escrow remedy); Washington -REv. CODE OF WASH. ANN. $\$ \$ 59.18 .070, .090$ (Supp. 1973) (warranty of habitability and remedies) and Foisy v. Wyman, 83 Wash. 2d 22, 515 P.2d 160 (1973); Wisconsin -Pines v. Perssion, 14 Wis. 2d 590, 111 N.W.2d 409 (1961), but cf. Posnanski v. Hood, 46 Wis. 2d 172, 174 N.W.2d 528 (1970); Maryland-Baltimore CiTY, MD., Public Local LAWs $\S \S 9-9$ and 9-14.1 (1971), and MONTGOMERY CounTY, MD. CODE, Fair Landlord-Tenant Relations, chs. 93A et seq. (1972) (Maryland does not have a rent withholding remedy of statewide application). See also UNIFORM RESDENTIAL LANDLORD \& TENANT ACr $\$ 4.105$ (1972) (court may order rent to be paid into court if landlord sues for rent or possession and the tenant counterclaims).

33. E.g., Fla. Stat. AnN. ch. 83, Part II, $\$ \S 83.001$ and 83.60 (1973); TenN. CoDe ANN. § 53-5501 et seq. (Supp. 1974).

34. The standard of uninhabitability which must be reached before a tenant may invoke the withholding remedy varies among the states. Generally, the threshold is reached by "substantial" housing code violations which endanger the health or safety of tenants.

35. See Flitton, Rent Withholding: Public and Private, 2 Harv. CTv. RightsCrv. LIB. L. Rev. 179, 190-93 (1966).

36. Ill. ANN. StaT. ch. 23, § 11-23 (Smith-Hurd Supp. 1975); Mrch. Comp. LAWS ANN. \$ 400.14(c) (Supp. 1975-76); N.Y. Social WeLFARE LAW \& 143-b (McKinney 1966) (Spiegel Act). For a comparative analysis of the New York and Illinois statutes, see Flitton, Rent Withholding: Public and Private, 2 Harv. Crv. RIGHTSCrv. LrB. L. Rev. 179, 181-84 (1966).

37. E.g., N.Y. Soclal Welfare LAW $\$ 143-b$ (McKinney 1966).

38. Simmons, Passion and Prudence: Rent Withholding Under New Yorks Spiegel Law, 15 BuFr. L. Rev. 572, 581-82 (1969). 
However, New York's recent experience with the Spiegel Act ${ }^{30}$ indicates that such public withholding remedies suffer the same fate as has traditionally befallen code enforcement programs: lack of strict enforcement due to pohicymakers' fear of potential counterproductive effects of such efforts. ${ }^{40}$

\section{b. Rent Abatement}

Perhaps the greatest shift in the alteration of the traditional landlord-tenant relationship, and the one most consistent with the application of contract principles, is rent abatement. This remedy allows tenants to remain in possession of the premises without paying rent ${ }^{41}$ or by paying a reduced amount until housing defects are remedied..$^{42}$ Once it has been determined that the landlord is at fault, the tenant generally pays only an amount equal to the reasonable value of the premises. ${ }^{48}$ In a sense, the effect of rent abatement is to reheve a tenant of his obligation to pay the contractual rent and to let the market, based upon a new set of facts, determine the rent level.

Rent abatement differs from the escrow method of rent withholding in a number of critical aspects. The rent escrow scheme normally requires a prior hearing to provide judicial authorization to the tenant's refusal to pay rent. In contrast, a tenant utilizing a rent abatement scheme takes the risk that a court will later determine that his actions were unwarranted. In addition to having to pay rent due and moving expenses, a mistaken tenant may have to pay attorneys' fees, court costs, and other statutory penalties. ${ }^{44}$ The abatement scheme is also more costly to the landlord simce the effect is to stop, rather than merely

39. N.Y. Social. WeLfare LAW § 143-b (McKinney 1966).

40. I. LOWRY, J. GUERON \& K. EISENSTADT, WELfare Housing IN NEW YorK CITY 25 (1972).

41. E.g., Conn. Gen. Stat. \$\$ 47-24b el seq. (1949); Iowa Code AnN. \$ 413.106 (1949); Ky. Rev. Stat. \$ 383.640 (1974). See also Model Residenttal LandlordTenant Code $\$ 2-207(2)$ (b) (1969); Uniform Residential Landlord and Tenant ACT $\$ 4.104(a)(3)$ (1972) (similar to MODEL CODE).

42. E.g., N.Y. Multi. DwELl. LAW $\$ 302$ (McKinney 1966).

43. If substantial preexisting housing code violations exist, the landlord might bo deprived of the entire rent. In Brown v. Southall Realty Co., 237 A.2d 834 (D.C. App. 1968), the court held that no rent was recoverable under an illegal lease. However, quasi-contractual recovery still remains a possibility.

44. E.g., CAL. CODE CTV. Pro. $\$ 1174$ (West 1954) provides that a tenant guilty of malicious unlawful detainer may be liable for treble damages. It is conceivable that a misinformed tenant might behave belligerently when confronted by a landlord demanding possession of the premises or past-due rent. It is unclear, however, whether such belligerency would constitute "malice" under the statute. See Note, Rent Withholding Won't Work: The Need for a Realistic Rehabilitation Policy, 7 LoYOLA L. REv. 66, 73 (1974). 
interrupt, the landlord's flow of rental income. ${ }^{45}$ Indeed, abatement of rent may be so costly to the impecunious landlord as to remove the only source for financing repairs.

A number of legal theories have been used to justify the rent abatement remedy. The two major theories are the illegal contract and implied warranty of habitability doctrines.

i. Illegal contract theory. Courts have sometimes used the longestablished principle that the law will not lend its sanction to enforce a contract with an illegal purpose as a means of allowing tenants to assert housing code violations as a defense to an action for rent. ${ }^{40}$ This doctrine, however, does not constitute a defense to an action for possession, nor can it be applied unless the landlord knew of the violations at the inception of the rental agreement. ${ }^{47}$ Thus, the illegal contract doctrine's utility has been mainly confimed to preventing landlords from collecting rent from tenants who have leased dilapidated premises whicl1 were in violation of housing codes. Even here the doctrine is of limited utility since its application forces termination of the lease, an undesirable result to the low-income tenant faced with a tight supply of low-rent housing.

ii. The implied warranty of habitability doctrine. Recognizing the limitations of outınoded legal principles and inadequate remedies, progressive jurisdictions have begun to imply warranties of fitness and habitability in urban residential leases. ${ }^{48}$ In most of these jurisdictions

45. There may be little practical difference between the procedures under an abatement and escrow rent withholding sclieme. As a good faith gesture, attorneys often recommend, and courts often order, the tenant to pay withheld rent into an escrow fund even under abatement type withholding laws. However, a major difference between the two methods in terms of cost to the landlord turns upon whetler the escrow fund is paid to the landlord or to the tenant upon final disposition.

46. The courts consider the illegal purpose to be the renting of premises which violate the housing code. E.g., Glyco v. Schultz, 289 N.E.2d 919 (Sylvaria, Ohio Mun. Ct. 1972); Longenecker v. Hardin, 264 N.E.2d 878 (Ill. Ct. App. 1970); Brown v. Southall Realty Co., 237 A.2d 834, 836 (D.C. App. 1968). Contra, Riley v. Nelson, 183 S.E.2d 328 (S.C. 1971); Posnanski v. Hood, 174 N.W.2d 528 (Wis. 1970).

47. See Saunder v. First Nat'l Realty Corp., 245 A.2d 836, 838 (D.C. App. 1968).

The implied warranty of habitability doctrine lias not been similarly restricted to preexisting defects. The California Supreme Court, in Green v. Superior Court, 10 Cal. 3d 616, 517 P.2d 1168, 111 Cal. Rptr. 704 (1974), avoided the question of whether the warranty of habitability applied to preexisting as well as supervening housing code violations. However, other courts which have considered the issue have concluded that the warranty of habitability encoinpasses both supervising and preexisting defects. E.g., Lemle v. Breeden, 51 Hawaii 426, 462 P.2d 470 (1969) (furnished dwellings); Kline v. Burns, 111 N.H. 87, 276 A.2d 248 (1971); Marini v. Ireland, 56 N.J. 130, 165 A.2d 526 (1970); Boston Housing Authority v. Hemingway, - Mass. —, 293 N.E.2d 831 (1973).

48. See cases cited at note 4 supra. However, the United States Supreme Court has held that there is no fundamental riglit to decent liousing. Lindsey v. Nornet, 405 U.S. 56 (1972). The Court there lield that the Constitution does not prohibit a state 
the implied warranty of habitability may be used as a defense in both actions for possession and actions for rent if the tenant is able to show that a "substantial" violation of the lousing code existed during the period rent was withheld. In addition, the tenant may have an affirmative cause of action against the landlord for breach of contract. ${ }^{40}$ The tenant, however, may still remain liable for the reasonable value of the use of the premises. ${ }^{50}$

If the implied warranty of habitability assumes all of the characteristics of a doctrine of caveat venditor and this fact becomes widely known, both the landlord and the tenant would possess a high degree of certainty about their powers and duties. The result would be lower transaction costs. ${ }^{51}$ However, economic efficiency will not necessarily result since such a warranty would provide tenants with incentives which might lead to inefficient responses. For example, tenants might be tempted to seek excessive repair and maintenance services from landlords since the tenants would benefit in the short-run. In order to forestall litigation, landlords may over-invest in repair and maimtenance.

The propriety of applying consumer protection principles, in the forn of warranties of quality, to the landlord-tenant relationship has been questioned on the ground that housing differs critically from other commodities. In the ordinary sales context, the implication of warranties of merchantability and fitness for use is based on the assumption that increased costs of assuring quality will be passed on to the ultimate consumer. ${ }^{52}$ Although the increased costs associated with the warranty

from treating the duties of the landlord and of the tenant as independent, rather than dependent. Further, the Court noted that the Constitution does not require state courts to treat the landlord's breach of a duty to maintain the premises as a defense in an unlawful detainer action for nonpayment of rent, so long as the tenant has a forum available to assert his claim for the landlord's breach.

49. E.g., Berzito v. Gambino, 63 N.J. 46, 308 A.2d 17 (1973).

50. Damages for breach of the implied warranty of habitability are usually calculated to be the difference between the contractual rent and the fair market value of the defective premises. See, e.g., Green v. Superior Court, 10 Cal, 3d 616, 638-39, 517 P.2d 1168, 1183, 111 Cal. Rptr. 704, 719 (1974). This formula presents a problem for lowincome tenants. When applied to many slum properties the traditional expectation formula may yield little or no recovery. If the dwelling is dilapidated and in an "impacted area," for example, the difference in the value of the premises with and without hot water may not be very great. In addition, it seems doubtful, given the significant lack of bargaming power on the part of low-imcome tenants, that a "fair" market value reflects an equitable market price. A solution to the problem of dainages, adopted by a New Jersey court in Academy Spires, Inc. v. Brown, 111 N.J. Super. 477, 268 A.2d 556 (1970), is to reduce the rent by a percentage corresponding to the diminution in the use and enjoyment of the premises caused by the landlord's breach.

51. By "transaction costs," economists mean real resources employed in bargaining and consummating an exchange.

52. See generally Note, Products Liability at the Threshold of the LandlordLessor, 21 HAST. L.J. 458 (1970); Note, The Doctrine of Caveat Emptor as Applied 
may drive marginal producers of that product out of the market, consumers are not entirely deprived of the product since numerous substitutes exist for most commodities. ${ }^{53}$ However, housing, or so the argument goes, is a "necessity for which there is no substitute." "54

This distinction between housing and other commodities is probably without merit. First, there is no simple dichotomy between necessities and non-necessities, and no simple meaningful comparisons of the importance of commodities can be made. Furthermore, it would appear that there are alternatives to the consumption of rental housing umits. This is evidenced by the observation that the demand for housing is not perfectly inelastic-individuals do respond to changes in prices by adjusting their consumption of housing. For example, if rents go up, people adjust by doubling up with relatives, moving into smaller or lower quality quarters, or moving out of a particular neighborhood.

\section{Receivership}

As a final resort, a number of states provide for court-appointed receivers to take control of buildings and to correct hazardous defects if the landlord fails to correct serious housing code violations after reasonable notice. ${ }^{55}$ While agencies which enforce housing codes have long enjoyed the power to obtain a court order requiring the owner to comply with code standards, ${ }^{56}$ the appointunent of a receiver has the advantage of replacing a recalcitrant landlord with a third party who can be counted on to take decisive action to correct serious defects. ${ }^{57}$ Although a few

to Both the Leasing and Sale of Real Property: The Need for Reappraisal and Reform, 2 RutGers-CaMden L. Rev. 120 (1970).

53. Note, Landlord's Violation of Housing Code During Lease Term Is Breach of Implied Warranty of Habitability Constituting Partial or Total Defense to an Eviction Action Based on Non-Payment of Rent, 84 HARv. L. Rev. 729, 733 (1971).

54. Id. at 733.

55. Connecticut-Conn. Gen. Stat. AnN. \& 19-347b (1969); Delaware-Del. Code ANN. tit. 25, §§ 5901 et seq. (1953); Mlinois-Ill. ANN. Stat. ch. 24, art. 1131-2 (Smith-Hurd Supp. 1974); Indiana-IND. ANN. STAT. \$§ 48-2333(3), (4) (Supp. 1971); Massachusetts-MASs. GEN. LAws ANN. ch. 111, \$§ 127H et seq. (Supp. 1975); Michigan-Mich. CoMp. Laws ANN. \& 125.535 (Supp. 1975-76); Minnesota-MinN. STAT. ANN. \$ 566.29 (Supp. 1975-76); Missouri-ANN. Mo. STAT. \& 441.570 (Vernon Supp. 1975); New Jersey-N.J. STAT. ANN. tit. 2A, \$§ 2A:42-85 et seq. (Supp. 197576) and tit. 40, \& 40:48-2.12(h) (1967); New York-N.Y. MULTz. Dwell. LAW \$ 309 (5) (McKinney Supp. 1974), N.Y. ReAl Prop. ACT AND Proc. LAW $\$ 769$ et seq. (McKinney Supp. 1974-75); Ohio-OHro Rev. Code ANN. $\$ 5321.07$ (1974); Rhode Island-GEN. LAWS of R.I. §§ 45-24.2-11, 45-24.3-19 (1971 and Supp. 1974); Wisconsin -Wisc. Stat. ANn. \$ 280.22 (Supp. 1974-75).

56. Except in Chicago, the mandatory injunction has rarely been used. Rosen, Receivership: A Useful Tool for Helping to Meet the Housing Needs of Low Income People, 3 HARv. CTv. RIGHTS-CTv. LiB. L. REv. 311, 316 (1968).

57. See generally Comment, Receivership of Problem Buildings in New York City and Its Potential for Decent Housing of the Poor, 9 ColuM. J. OF L. \& Soc. Prob. 309 
states have recently granted tenants standing to initiate receiverships of the buildings in which they reside, ${ }^{58}$ the receivership inechanism remains primarily a government-initiated remedy.

Before the initiation of the receivership, a hearing is usually held to determine the existence of specific violations. If the court determines that the landlord has failed to provide essential services, the rent is deposited with the court-appointed receiver until the code violations are corrected. The receiver can be a private party, a social service agency, or a municipality responsible for using the deposited funds for specific purposes. $^{59}$ If the rental payments are not sufficient to finance the repairs, some statutes allow the receiver to obtain additional money from private or public loans. In doing so, prior first liens are converted into second liens, imposing particularly heavy costs on lenders and, therefore, landlords. ${ }^{80}$ As long as the tenant continues to pay rent into the escrow, the landlord is precluded from evicting the tenant for nonpayment of rent. The receivership is usually terminated after the housing code violations have been reniedied and the building restored to a safe condition. Control of the building and the surplus of the rent escrow fund are then returned to the owner.

Receivership is potentially the most costly remedy to the landlord. Unlike the repair and deduct and withholding remedies, which are based on each tenant's initiative, receivership remedies are conducted on a building-wide basis. Even those tenants who would not normally invoke a withholding remedy are forced to pay their rent into a court-created escrow rather than to the landlord. Thus, while repair and deduct and withholding remedies are dependent upon the resources and willingness of tenants to accept the risks inherent in such tenant remedies, the receivership remedy is tied to the greater resources of a governmental agency. Moreover, unlike rent withholding, the control and management of the building is removed under a receivership approach. Indeed, the rationale behind receiverships in the rehabilitation of dilapidated buildings is to interpose a third party who is relatively unrestrained by profit considerations and, thus, more likely to remedy housing code violations.

(1973); Pratt, Receivership in the Rehabilitation of Urban Housing, 2 HARV. Crv. Rights-Crv. Lib. L. Rev. 219 (1967); Gribetz, New York City's Receivership Law, 21 J. of Housing 219, 298 (1964); Rosen, Receivership: A Useful Tool for Helping to Meet the Housing Needs of Low Income People, 3 HaRv. Civ. Righrs-Civ. LiB. L. REv. 311 (1968).

58. E.g., Munn. Stat. Ann. $\$ 566.29$ (1973); Mass. ANn. Laws ch. 111, $\$ \$ 127 \mathrm{H}$ et seq. (Supp. 1966); N.J. STAT. ANN. tit. 2A, §§ 2A:42-85 et seq. (Supp. 1974-75); Wisc. Stat. ANn. \$ 280.22 (Supp. 1974-75).

59. See N.Y. Multu. Dwelling Law \$ 309(5)(d)(1) (McKinney 1974).

60. See Note, Preference Liens for the Costs of Repairing Slum Property, 1967 WASH. U. L.Q. 141 (1967). 
By allowing the issuance of certificates and the interposition of prior liens and assistance from municipal receivership funds, receivers are more likely to incur necessary expenses to remedy the defects. In New York, receivers are permitted to go even beyond the mere correction of lousing code violations by "relrabilitating" the premises. ${ }^{61}$

\section{Retaliatory Eviction Laws}

Tenant-imitiated code enforcement mechanisms, especially rent withholding, are relatively inpotent unless coupled with assurances to tenants that they will not be punished for invoking such devices. Tenants are protected by case law or statute against retaliatory evictions and rent increases in at least twenty-six jurisdictions. ${ }^{62}$ Most of these laws, however, only purport to protect tenants against actions taken by landlords with a retaliatory or punitive motive. The policy underlying the retaliatory eviction and rent increase laws is that landlord action to deter exercise of tenant rights is against public policy. These laws, however, do not purport to immunize tenants permanently from the economic consequences of their actions. ${ }^{63}$

Under sucl statutes, the determination of the landlord's motive is of critical miportance. Many states provide that disadvantageous

61. N.Y. Multi. Dwelling LAW $\S 309$ (5) (d) (McKinney 1974).

62. Alaska-Alask. Stat. tit. 34, $\$ 34.03 .310$ (Supp. 1974); Arizona-ARZz. Rev. STat. tit. 33, § 33-1381 (1974); California-CaL. CN. CoDE § 1942.5 (West Supp. 1975), Schweiger v. Superior Ct. (Bonds), 3 Cal. 3d 507, 476 P.2d 97, 90 Cal. Rptr. 729 (1970); Connecticut-ConN. Gen. Stat. AnN. tit. 19, § 19-375a (Supp. 1975); Delaware-DEL. CODE ANN. tit. 25, \& 5516 (1974); District of Columbia-D.C. Housing REGS. $\$ 2910$ et seq. (1970), Edwards v. Habib, 397 F.2d 687 (D.C. Cir. 1968), cert. denied, 393 U.S. 1016 (1969); Hawaii-HawaII REv. STaT. tit. 28, \& 521-74 (Supp. 1974); Illinois-Ill. ANN. Stat. ch. 80, $\$ 71$ (Smith-Hurd 1966), Clore v. Fredman, 59 IIl. 2d 20, 319 N.E.2d 18 (1974); Kentucky-KY. REv. STAT. tit. 32, \$ 383.705 (Supp. 1974); Maine-ME. Rev. Stat. ANN. tit. 14, \$ 6001 (1974); Maryland-MD. ANN. CODE, REAL PRoperTy tit. 8, § 8-208.1 (Supp. 1974); Massachusetts-MASs. GEN. LAWS ANN. ch. 186, § 18 (Supp. 1975); Michigan-Mich. CoMp. Laws ANN. \$ 600.5720 (Supp. 1975); Minnesota-MinN. STAT. ANN. $\$ \$ 566.03$, 28 (Supp. 1975-76); Nebraska-Rev. Stat. NeB. § 76-1439 (1974 Cum. Supp.); New Hampshire-N.H. Rev. Stat. ch. 540, §§ 13a, c (Supp. 1972); New Jersey-N.J. STat. ANN. tit. 2A, § 2A:42-10.10 (Supp. 1975); New York-N.Y. UnconsoL. Laws, $\$ 8590,8609$ (McKinney 1974); Ohio-Omo Rev. Code ANN. tit. 53, § 5321.02 (Supp. 1974); OregonORE. LAws ch. 559, § 32 (1973); Pennsylvania-PA. STAT. ANN. tit. 35, § 1700-1 (Supp. 1974) (bars eviction while tenaut is withholding rent under statute); Rhode IslandR.I. Gen. Laws ANN. ch. 20, § 34-20-10 (1970); Tennessee-TENN. Code ANN. § 535505 (Supp. 1974) (general statement); Virginia-CODE OF VIRGINIA ch. 13.2, art. 6, $\S 55-248.39$ (Supp. 1975); Washington-Rev. CoDE OF WASH. tit. 59, ch. 59.18, \$§ 240, 250 (Supp. 1973); Wisconsin-Dickhut v. Norton, 45 Wis. 2d 389, 173 N.W.2d 297 (1970).

63. E.g., Six month presumption - ORE. LAWS ch. 559, § 32 (1973); ARIz. REv. StaT. tit. 33, \$33-1381 (1974); ninety-day presumption-Mass. GEN. LAws ANN. ch. 186, $\$ 18$ (Supp. 1975); Mich. CoMP. LAWS ANN. § 600.5720 (Supp. 1975). 
changes in the landlord-tenant relationship are rebuttably presumed to have been caused by retaliatory motives if such changes occur within a specified time after a tenant complains to a governmental agency or withholds his rent. ${ }^{64}$ A landlord may be able to prove that rent increases were motivated by pecuniary reasons by introducing into evidence receipts and bills which indicate the costs the landlord incurred in repairing the premises. Given the economic phight of many innercity landlords, courts may be sympathetic to the landlord's position rather than risk the possibility that the landlord will abandon the building. Other jurisdictions do not provide courts with this kind of discretion; they provide for a conclusive presunption that any of a number of enunerated actions by landlords arise from retaliatory motives. ${ }^{\circ 5}$

The economic effects of retaliatory eviction laws are highly variable. In one sense, however, they can be viewed as miniature, temporary rent control laws which preserve the existing rent status quo in the face of a changed buyer-seller relationship. The force of the rebuttable or conclusive presumption tends to deter landlords from raising rents for the statutory period. Thus, landlords are forced to operate under increased operating and maintenance costs without a commensurate increase in rental income in the hope of recouping losses as soon as legally feasible. The temporary and rather limited scope of retaliatory eviction/rent increase laws is unlikely to cause many landlords to abandon. However, the rebuttable presuniption undemiably does impose costs upon landlords. Thus, when the landlord feels legally "safe" in raising rents the increase may be larger than otherwise would have been the case.

Table 1 presents the status of habitability laws in the 50 states and the District of Columbia as of January 1972. This cut-off date was chosen in order to conform to the University of Michigan Survey data that will be used in the empirical analysis which follows.

Table 1

Status of Habitability Laws in January $1972^{66}$

" 1 " Indicates presence of the habitability law. " 0 " indicates absence.

\begin{tabular}{lcccc} 
State & $\begin{array}{c}\text { Repair \& } \\
\text { Deduct }\end{array}$ & $\frac{\text { Withholding }}{\text { Receivership }}$ & $\begin{array}{c}\text { Retaliatory } \\
\text { Eviction }\end{array}$ \\
\hline Alabama & $\frac{0}{0}$ & 0 & 0 & 0 \\
Alaska & 0 & 0 & 0 & 0
\end{tabular}

64. E.g., CAL. Crv. CoDE $\$ 1942.5$ (West Supp. 1975) (rebuttable presumption apphies for 60-day period; can be invoked only once in a 12-inonth period). See generally Note, Retaliatory Eviction: The Right to Challenge the Landlord's Motives, 21 SYRACuse L. REv. 986 (1970); Note, Landlord and Tenant-Burden of Proof Required to Establish Defense of Retaliatory Eviction, 1971 WISc. L. REv. 939 (1971).

65. See, e.g., Hawan Rev. Stat. tit. 28, § 521-74 (Supp. 1974).

66. Table 1 was compiled through the authors' review of state statutes and deci- 


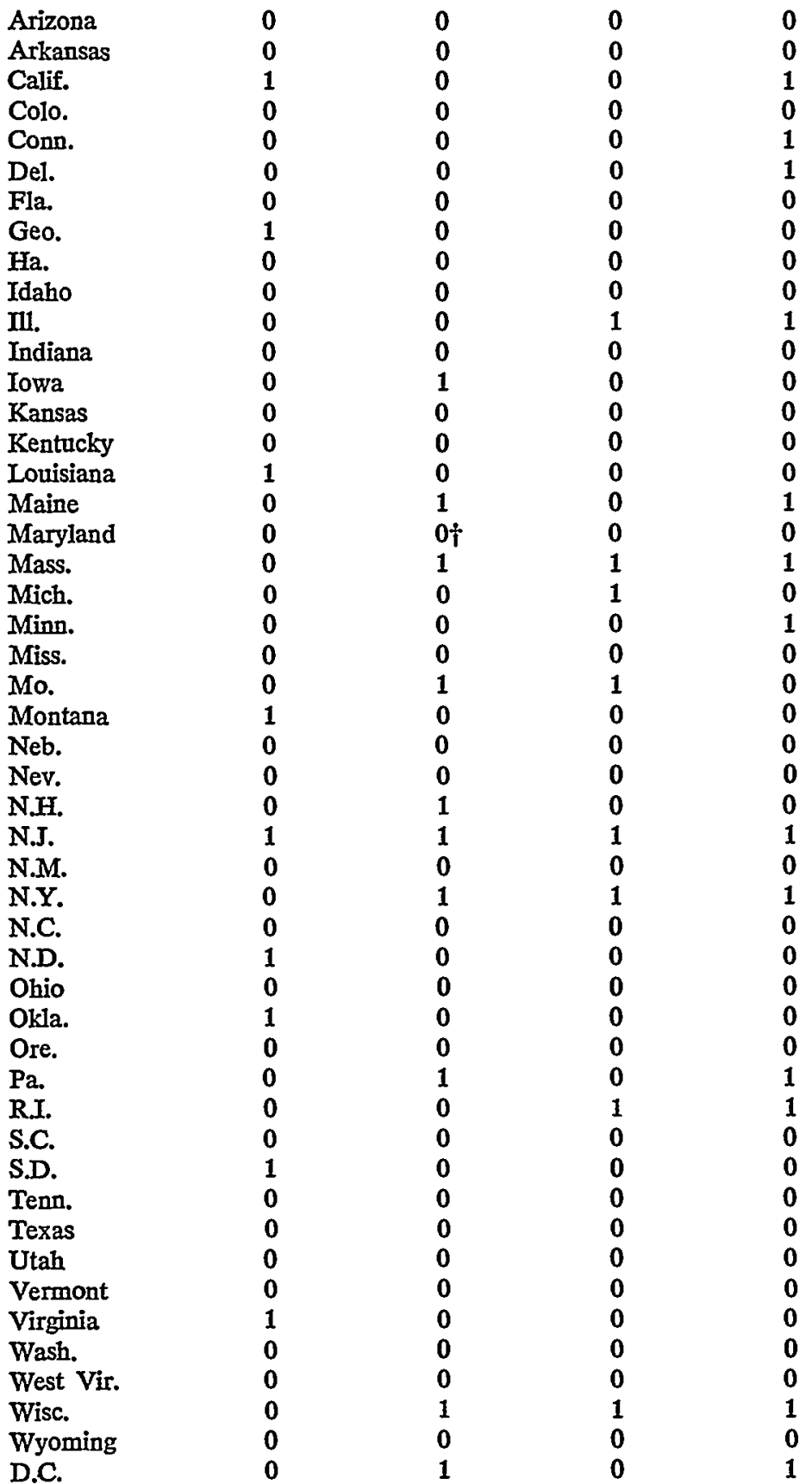

i Indicates that local jurisdictions have habitability laws.

sions. Since local variations in non-habitability law states and varying interpretations of laws on a trial court level make precise categorization of the state of the law in various jurisdictions difficult, the information used in preparing this table was checked against three independent sources. First, a systematic check of the states with laws of uncertain specification or interpretation was made by telephone calls to legal service, 
II

\section{Economic ANaLysis of Habitability LaWs}

The impact and merits of the previously described minimum quality housing laws may be assessed with the tools of economic analysis. Section A presents an argument that housing, despite some characteristics which differentiate it analytically from other commodities, ${ }^{07}$ does exhibit fairly conventional supply and demand behavior. That is, people do react to prices in the housing market; if prices are high, landlords are more willing and tenants are less willing to participate in a given housing market. This argument has not been given sufficient emphasis in the legal hiterature on the subject and is critical to any determination of cost sharing between landlords and tenants. Section B atteinpts to illustrate the utility of such a perspective in the evaluation of laws that seek to regulate housing quality by legal sanctions.

\section{A. The Housing Supply and Demand}

In their debate in the Yale Law Journal on the enforcement of housing codes, Ackerman and Komesar make some rather restrictive assumptions about the nature of the supply process. These assumptions substantially affect the respective conclusions each author reaches. Ackerman, who concludes that the increased costs of housing code enforcement will not be passed on to tenants, begins his discussion with a detailed construction of a hypothetical world in which change in the number of housing units is ruled out. ${ }^{08}$ This world is not purported to mirror reality, but only to provide a convemient conceptualization of housing markets. Ackerman's conclusions can be questioned on the basis that his abstract model may depart quite severely from reality. Although his assuniption of a perfectly inelastic supply of dwellings may be appropriate in the extreme short-run, it is contradicted by both empirical evidence and the theories of supply of low-income housing that have been advanced by economists. ${ }^{80}$

poverty law, and tenant organization offices. The information collected in this manner was then checked against a table prepared by the Joint Center for Urban Studies of the Massachusetts Institute of Technology and Harvard University. Counclu of STATE Governments, A PLace to Lrve: Housng Policy In the States 46-47 (1974). A revised compilation was then checked against an independent search conducted by Richard E. Blumberg and Brian Robbins, staff attorneys of the National Housing and Economic Development Law Project, Berkeley, California. The results of their investigation will appear in Blumberg \& Robbins, Beyond U.R.L.T.A.: A Program for Achicving Real Tenant Goals, 11 HARV. CTv. RIGHTS-Crv. LIB, L. REV. - (1976). The final compilation of laws appears in the Appendix.

67. Examples are long life expectancy, importance in the household budget, and heavy transaction costs associated with changing tenancy.

68. Ackerman, Slum Housing Markets, supra note 9 at 1102-04.

69. See note 74 infra and accompanying text. 
Komesar correctly attacks Ackerman's unrealistic assumptions. But the alternative scenario that he presents is itself rather extreme. In Komesar's world, the landlord can adjust the number of units quite rapidly in response to changes in demand, price, or other market circumstances. ${ }^{70}$ Komesar then argues that landlords, in response to minimum quality housing laws, will abandon their properties in great nunibers until the price for remaining units is pushed high enough to cover the increased costs of providing low-rent dwelling units. ${ }^{71}$ This argument, however, neglects the durability of the housing stock, which may cause the current opportunity costs of providing housing ${ }^{72}$ to be less than the net revenues to the property in its present form. Although conditions may render provision of housing a less profitable activity than expected at the time a building was constructed, its alternative uses may be quite limited, due to the particular attributes of its structure and location. Therefore, many units will remain in service even though net revenues have been reduced. ${ }^{73}$ This latter view is consistent with empirical studies of the supply and demand functions of the housing market. Existing estimates find elasticities close to one, a value which suggests a conventional supply process rather than either of the extreme hypotheses posited by Ackerman and Komesar. ${ }^{74}$

These empirical results are consistent with the widely utilized filtering theory. When structures deteriorate, through age, obsolescence, lack of maintenance, poor construction, or the decline of the neighborhood, the original residents often find that the structures no longer satisfy their demands, and seek housing elsewhere. New residents move into the old structures because they have lower incoines than the previous residents and consequently are willing to purchase lower quality shelter at a lower cost. This process is referred to as "filtering," or more precisely, "down-filtering." The lowcost housing supply relies heavily on the filtering-down process simce very little housing is constructed for the low-cost market. Since higlier income groups tend to prefer new lousing, there is a constant downward pressure on existing housing umits, as new, high rent dwellings are constructed.

As more affluent residents move into newer umits, the continuous

70. Komesar, Critique, supra note 10 at $1186-92$.

71. Id. at 1187-88.

72. This is related to the foregoing of alternative uses of the property.

73. This argument is, of course, invalid in the "extreme long run" where all things are allowed to adjust fully.

74. deLeeuw, The Demand for Housing: A Review of Cross-Section Evidence, 53 Rev. of Econ. \& Stat. 1 (1971); Muth, The Demand for Uniform Housing, in THE Demand For DuRable Goods 29 (A. Harberger ed. 1960); M. Reid, Housing and INcome (1962); Lee, Housing and Permanent Income: Tests Based on a Three-Year Reinterview Survey, 50 Rev. OF Econ. \& STat. 480 (1968). 
flow of additional units into the lowest quality level results in abandonment or demolition of the least desirable of these units. Thus, the stock of low quality housing is maintained by a fairly steady flow into and out of this low quality category. The relative magnitude of these movements is crucial for the determination of the number of low quality umits. The flow into or out of a housing quality category will vary as a function of market conditions, such as changes in rents, factor prices, and the legal environment.

Housing quality laws inay have a substantial effect upon the filtering process. Landlords in the low quality market whose structures werc only marginally viable before the law was passed will either raise rents or abandon the structure. Landlords owning higher quality units who might have been willing to allow their units to deteriorate may beconie unwilling to do so because of the imcrease in the cost of maintaining low quality dwellings. These landlords may even upgrade the structure more than legally required and serve a higher income clientele. Clearly, different landlords will be faced with different conditions and will respond in different ways. ${ }^{75}$

A decrease in the nuniber of dwellings offered in the low-mcone market would force up rents. If tenants, believing that the benefits of the law are worth the increased costs, then remain in the housing nuarket, the landlords who mitially left the market will eventually be reattracted because of the likelihood that sufficient rent can be charged to cover

75. Some commentators appear to believe that the profitability of slumlordism will determine whether landlords will pass the increased costs due to code enforcement on to low-income tenants. For example, one commentator has stated:

The idea that improvements will necessitate sharp increases in rent presupposes that landlords must pass their costs on to the tenants. This, in turn, raises the question of the profitability of slum rental units. Put more bluntly, are slum tenants being "gouged?"

Comment, Rent Withholding and the Improvement of Substandard Housing, 53 CALIF. L. REv. 304, 320 n.83 (1965). See also Levi, Focal Leverage Points in Problems Relat. ing to Real Property, 66 CoLum. L. Rev. 275, 276 (1966), asserting that slumlordism is a "highly profitable business."

The underlying factor in determining whether costs will be passed on, however, is not the profitability of slumlordism, but rather the supply and demand elasticities of the low-rent housing market. Landlords are not public charities. Even a landlord with a high profit margin would not voluntarily absorb increased costs, unless the prevailing demand and supply conditions of the housing market forced him to do so.

Further, recent evidence indicates that slumlordism is not as profitable as these commentators would have one believe. For example, Sternlieb found that the average "actual return on investment in terms of the overall parcel value is . . . in the neighborhood of 10-12 percent." G. SternLIEb, THe TENEMENT LANDLord 88 (1966). Rapkin estimated the return in New York City's West Side Urban Renewal Area to be about 10 percent. C. RAPkIN, The ReAl Estate MarkEt in aN URBan Renewal AREA 81-82 (1959). In a later study of New York City while under rent control, Sternlieb found a predominance of slum housing yielding less than six percent of market value even before a correction for a management fee was made. G. STRRNLIEB, THE URBAN HousING DILEMMa 139 (1972). However, Sporn found an average rate of return ex- 
the new costs. But if some households react to the rent increase by doubling up with relatives or friends or by otherwise leaving the housing market, rents would stabilize at a level that would not completely compensate landlords for the added costs. Nonetheless, rents would stabilize at a higher level than initially. Rents would remain at the initial level only if deinand for housing is perfectly elastic (that is, if consumers forced to pay even small rent increases would leave the inarket). This is an unlikely case, since moving often entails substantial hardship.

\section{B. Application of Analytical Tools}

This section demonstrates the application of supply and demand concepts to an analysis of the effect of habitability laws. This theoretical analysis leads to three conclusions. First, except under the most unlikely circumstances, ${ }^{76}$ housing rents must increase if a law is implemented and enforced so as to impose additional costs on landlords. ${ }^{77}$ Second, if tenants feel that they derive no benefit from the law, price increases will be less than the additional costs iniposed on landlords. Third, if the tenants do place some positive evaluation on the law, price increases will be larger-perhaps large enough to offset completely the additional costs associated with the provision of the new, higher level of services. ${ }^{79}$

It was argued above that low-cost housing supply occurs mainly as a result of a filtering process, and that the very nature of this process gives rise to opportunities for inarket adjustment of the quantity of housing services provided. Further, it was noted that there are opportunities for tenants to adjust to price changes. These adjustments give rise to conventional supply and demand functions for housing services. Given the existence of a relatively conventional supply-demand relationship, sone of the possible reactions to the introduction of habitabil-

ceeding 20 percent in a Wisconsin study. Sporn, Empirical Studies in the Economics of Slum Ownership, 36 LAND EcoNomics 336 (1960). In short, there is no convincing evidence that landlords of low-cost housing uniformly enjoy large profit margins.

76. This "unlikely circumstance," as discussed below, is the case where the denand for lousing is perfectly elastic, i.e., even with a very slight increase in rents all tenants would choose not to rent dwellings in the given housing inarket. This nay occur if tenants simply "could not afford" to pay for the increase. However, it is unlikely that all tenants have such rigid budgets that they would undergo the psychic and material costs of moving. Furthermore, all existing empirical results refute a condition of perfect elasticity.

77. It is clear that these laws entail greater costs to landlords, since otherwise landlords would have no aversion to providing these benefits without being coerced by the law. The nature of cost increases for the landlord includes increased uncertainty with regard to inaintenance and litigation costs and increased expenditures to meet whatever standards are adopted by the court or legislature.

78. Although this section is written to avoid unnecessary conplexity, it is somewhat technical. Therefore, the reader who is willing to grant the above conclusions without demonstration of their derivation may skip to part III. 
ity laws can be explored. One possible reaction to a habitability law is that the demand curve changes very hittle, or not at all. This would be the case where tenants are unaware of the law, or where they place bittle value on protection it might provide. In either case, tenants benefit hittle, if at all, from the law. This possibility is admittedly contrary to basic motivations behind the development of tenant-mitiated code enforcement mechanisms. Although the price increases may be small in this case, no benefits result-only costs.

This imitial situation is illustrated in figure 1 , where $\mathbf{P}$ is the demand and supply equilibrating price. The horizontal axis measures the nunber of dwelling units within some specific housing quality category. The vertical axis represents the rental price paid for these housing units.

Figure 1

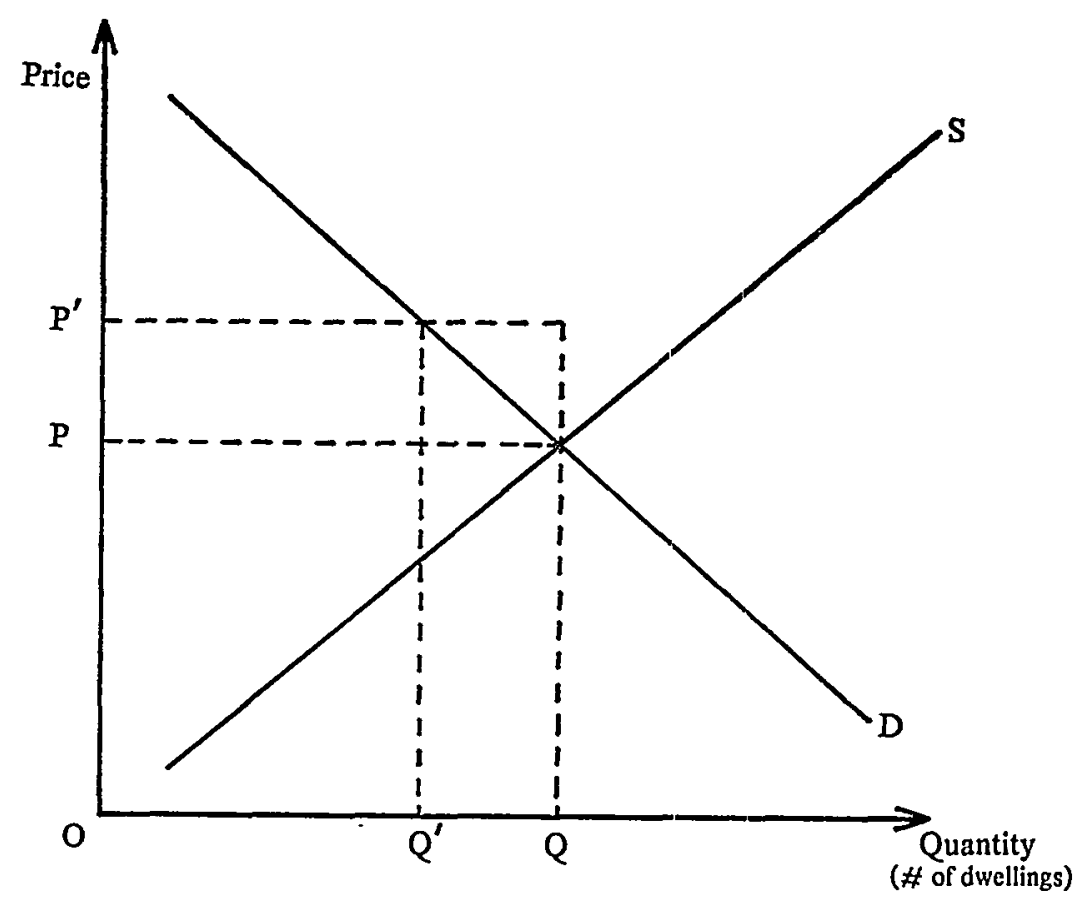

How will the additional costs resulting from the law be divided between landlord and tenant? More directly, how much of the cost, if any, will the landlord be able to pass on to the tenant? Clearly, the answer depends on the degree to which tenants respond to price changes by reducing their consunuption. As expressed by economists, the elasticity of demand with respect to price (price elasticity) will determine cost sharing configurations. It is clear from figure 1 that for landlords simply to raise prices and attempt to rent all the existing units at, for example, 
$\mathrm{P}^{\prime}$ would not work. The demand curve, which is assumed not to shift in response to the new law, indicates that at the new price not all units would be rented. Instead, tenants would choose to rent only $Q^{\prime}$ units. This would appear to bring about the competitive price cutting that Ackerman relies upon to keep landlords from raising prices. However, at the old price not all dwellings currently offered in the market would remain. The marginal unit which would be forced out of the market by a reduction in rent of one dollar (as represented by the supply curve) similarly is forced out of the inarket by an increase in cost of one dollar. The preceding argument can be formalized by a further assumption: landlords react by removing units from the market as a consequence of increased costs in the same way that they react to an equivalent reduction in rent, smce in either case the landlord's profit per unit is decreased. ${ }^{70}$

Given these assuniptions, the increased costs of production of housing service can be treated as being similar to a unit tax on dwellings, ${ }^{80}$ as illustrated in figure 2.

Figure 2

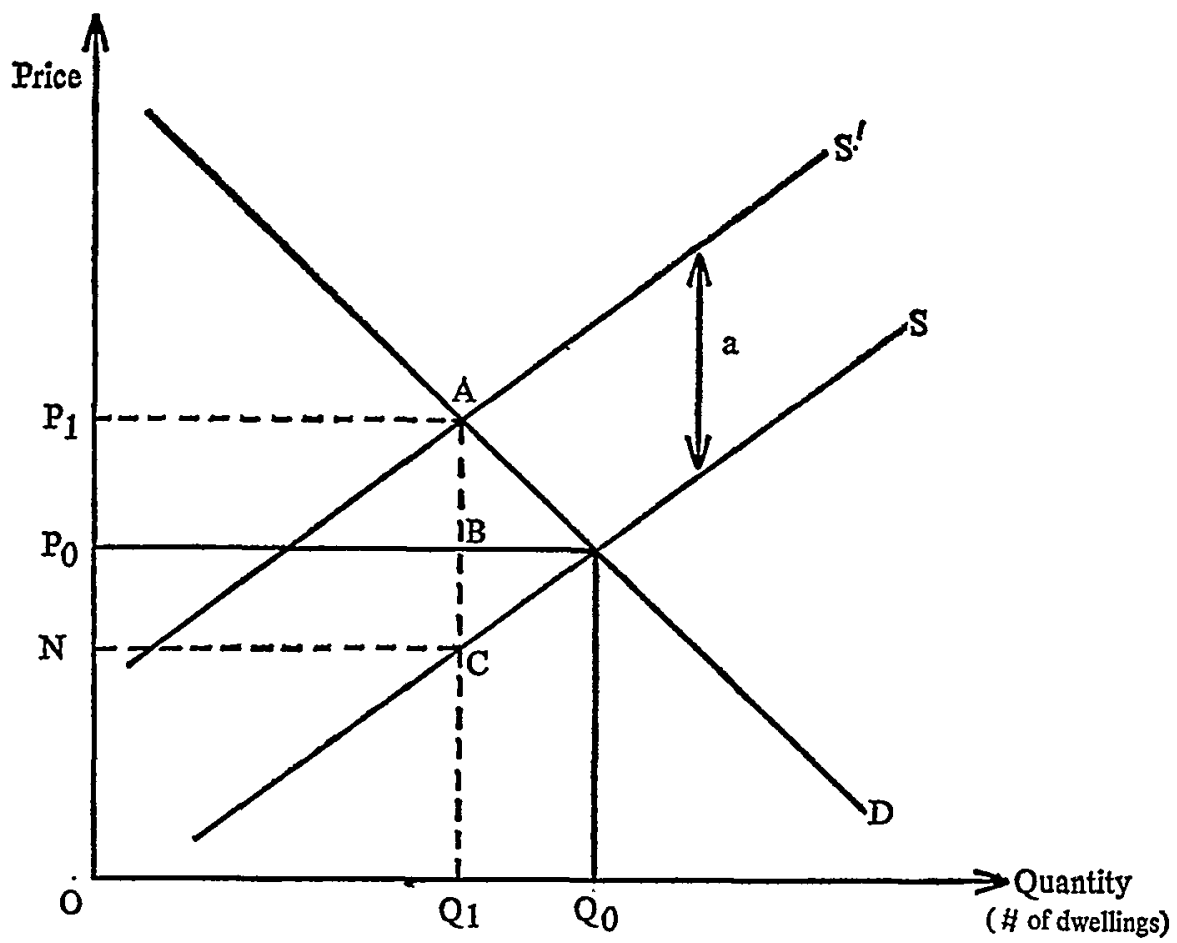

79. This assumption is not a trivial one. A change in rents is usually more certain in its effects and more readily perceived by the landlord than a change in cost. Still, a common assumption in economics is that people have information and behave rationally.

80. This derivation is similar to that in R. Musgrave, The Theory of Public FINANCE 292 (1959). 
The additional costs cause an upward shift in the supply curve equal to the distance $a$. The new supply curve is represented by $\mathrm{S}^{\prime}$ and the new equilibrium price is $P_{1}$. The distance $a$ is, by definition equal to the additional costs imposed by the habitability law, since the landlord is as willing to provide units along $S^{\prime}$ after the law as he was along $S$ before the law. Thus, the tenant experiences an increase in price of $P_{1}-P_{0}$, and the landlord experiences a reduction in price equal to $P_{0}-N$ as a result of the "tax" of additional costs. The ratio of the burden can be expresed as $\left(\mathrm{P}_{0}-\mathrm{N}\right) /\left(\mathrm{P}_{1}-\mathrm{P}_{0}\right)$, or $\mathrm{AB} / \mathrm{BC}$. Noting that the distance $A B$ is the change in quantity times the slope of the demand curve, and that $\mathrm{BC}$ is the change in quantity times the slope of the supply curve, the ratio of the burden can be expressed in terms of demand and supply elasticities as follows:

(1) $\mathrm{P}_{1}-\mathrm{P}_{0}=\mathrm{AB}=\left(\frac{\mathrm{dP_{ \textrm {D } }}}{\mathrm{dQ}}\right) \cdot \Delta \mathrm{Q}$
(2) $\mathrm{P}_{0}-\mathrm{N}=\mathrm{BC}=\left(-\frac{\mathrm{dP}_{\mathrm{B}}}{\mathrm{dQ}}\right) \cdot \Delta \mathrm{Q}$

Thus, the ratio of the burdens is equal to the ratio of supply and demand elasticities. To solve for the change of price as a function of the change in costs, 1 is added to both sides of equation (3), resulting in the following:

$$
\text { (3) } \frac{P_{n}-N}{P_{1}-P_{0}}=\frac{B C}{A B}=\frac{\left(-\frac{d P_{s}}{d Q}\right) \cdot \Delta Q}{\left(\frac{d P_{D}}{d Q}\right) \cdot \Delta Q}=\frac{-\frac{d Q}{d P_{D}}}{\frac{d Q}{d P_{S}}}=\frac{-\frac{d Q}{d P_{D}} \cdot \frac{P}{Q}}{\frac{d Q}{d P_{s}} \cdot \frac{P}{Q}}=\frac{-\varepsilon_{D}}{\varepsilon_{B}}
$$

where $\varepsilon_{\mathrm{D}}$ and $\varepsilon_{\mathrm{s}}$ are the elasticities of demand and supply respectively.
(4) $\frac{P_{0}-N}{P_{1}-P_{0}}+\frac{P_{1}-P_{0}}{P_{1}-P_{0}}=\frac{-\varepsilon_{D}}{\varepsilon_{B}}+\frac{\xi_{B}}{\varepsilon_{s}}$
(5) $\frac{P_{1}-N}{P_{1}-P_{0}}=\frac{\varepsilon_{8}-\varepsilon_{D}}{\varepsilon_{8}}$

Thus,

$$
\text { (6) } P_{1}-P_{0}=\left(P_{1}-N\right) \cdot\left(\frac{\varepsilon_{s}}{\varepsilon_{B}-\varepsilon_{D}}\right)=a \cdot\left(\frac{\varepsilon_{B}}{\varepsilon_{8}-\varepsilon_{D}}\right)
$$

We can evaluate equation (6) using the empirical findings of deLeeuw and Ekanem. They found a supply elasticity of +0.7 and a demand elasticity of -1.2 in the low cost housing market. ${ }^{81}$ Since a price change, $\Delta \mathrm{P}$ in this case, is the difference between new price, $\mathrm{P}_{1}$, and the old price, $\mathrm{P}_{0}$, we have $\Delta \mathrm{P}=\mathrm{P}_{1}-\mathrm{P}_{0}=0.37$; i.e., 37 percent of the costs associated with the habitability law will be passed on to the tenant under the present assumption of no compensating benefits.

81. deLeeuw \& Ekanem, The Supply of Rental Housing, 61 AM. EcoN. Rev. 806 
There are other possible supply-demand reactions. If the tenant does have a positive evaluation of the protection he receives from the law, both curves may shift and new supply and demand functions replace the old ones. The new housing supply functions, $S^{\prime}$, will include the costs associated with the habitability law and, therefore, will be to the the left of the old one. The new housing demand function, $D^{\prime}$, relates to a higher housing quality and, therefore, will be to the right of the old one.

If the tenants' evaluation of the benefits is equivalent to the increase in cost, the quantity exchanged will be unchanged, with the increase in price equal to that of the cost. This result is illustrated in figure 3. It is even possible that the equilibrium quantity in a given low quality category would increase, with still higher prices if the deinand shift were large enough. This might occur if, for example, the protection provided to tenants would allow occupancy of low quality umits by individuals who previously avoided such housing because of the unreliability of service.

Figure 3

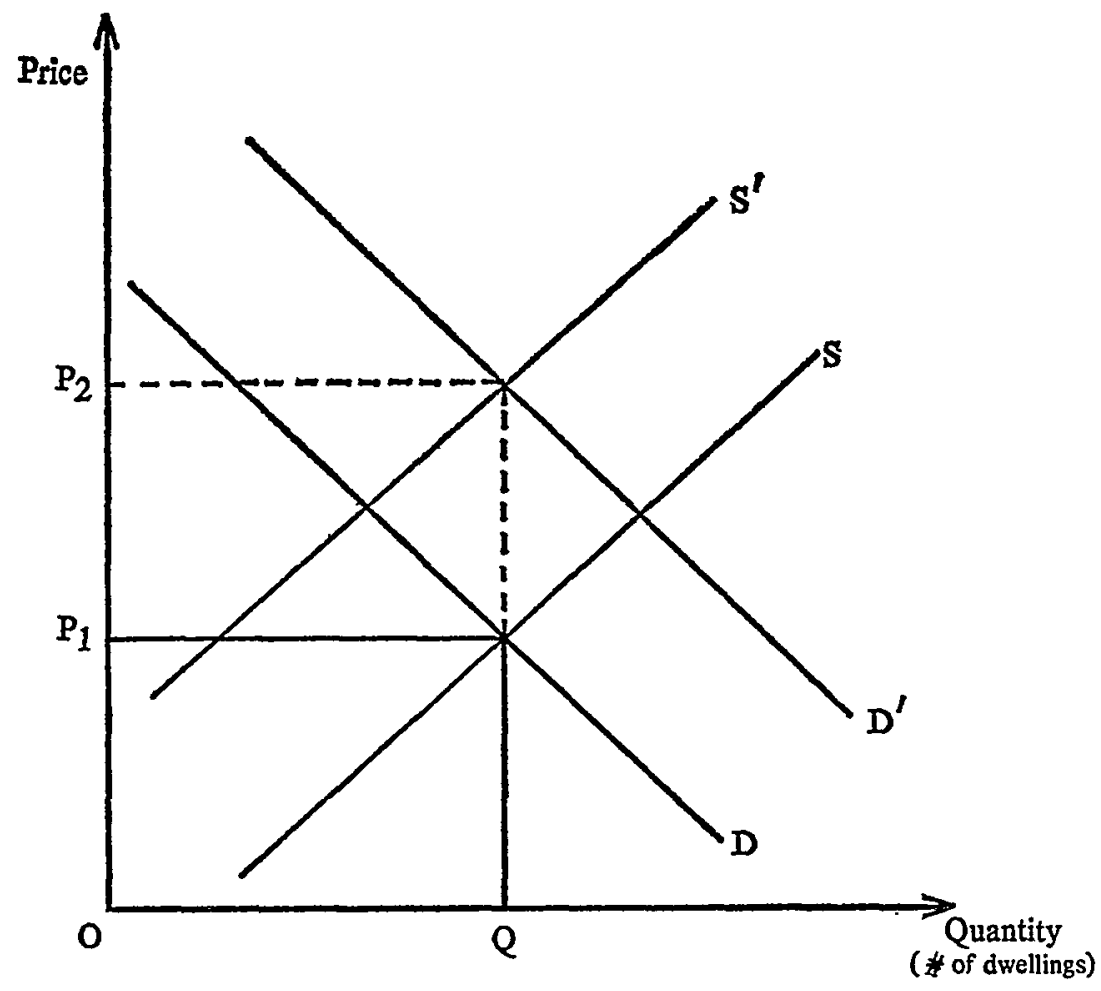

(1971). These elasticities are subject to debate because prices in all parts of the housing inarket in deLeeuw's study inove together. However, whatever bias exists would affect both supply and demand estimates similarly, and thus approximately offset the computation of cost allocations. 
So far the effects on the above-standard housing market resulting from price and cost changes in the below-standard categories have been ignored. In the first case, where the demand function is unchanged by the implementation of the habitability law, and as a result the number of units in the substandard categories is reduced, the question must be asked-what lappens to the umits and the households as the number of dwellings is reduced? For the lowest quality categories, households may leave the area or double up with relatives or friends (which may in itself be a housing code violation). The most likely response for landlords is probably abandonment. For the better quality, but still below standard, categories the quantity adjustments may occur in part in the form of a reduction in the number of umits filtering down front the above-standard category. This would increase supply in the above-standard categories. At the same time, however, tenants previously in substandard units may choose to rent standard units as the price differential narrows. Thus, with the increased demand, the effect on prices in the standard-quality and better-quality categories would be small even with an increase in supply in these categories.

\section{III}

\section{SOME EMPIRICAL FINDINGS}

In the previous section we discussed low knowledge of supply and demand relations and of their behavior in the light of habitability laws could help evaluate the effects of such laws. Empirical estimation of housing supply and demand curves is a rather demanding undertaking. While such results should be informative as to the costs and benefits of habitability laws, such estimation is beyond the scope of this Article. We can, however, test the validity of Ackerman's assertion that the costs of habitability laws will not be passed on through higher rents. Such an assertion would be refuted by empirical evidence that habitability laws are associated with rent increases. While statistical techniques cannot determine cause and effect relationships, they can indicate whether habitability laws and high rents are correlated. Should careful statistical analysis reveal that the passage of habitabihty laws is not significantly associated with rent imcreases, there would be no need to take the laborious step of first estimatimg cost increases and then determining their distribution between landlord and tenant. The absence of rent increases under habitability laws means either that there were no cost increases that landlords sought to pass on, or that landlords assumed the entire burden. The latter possibility is most unlikely, as was argued in the previous section. On the other hand, should statistically significant relations between habitability laws and rent increases be uncovered, this information could beconie a first step in a further investigation of how cost mcreases are distributed bețeepn landlord and tenant. 
In order to determine whether increased costs associated with minimum housing quality laws were in fact passed on to low-income tenants, ${ }^{82}$ housing expenditures of low-income households were analyzed with the aid of inultiple regression techniques. ${ }^{83}$ The analysis was conducted on data from a survey of 5,000 households undertaken in the years 1968-72 by the University of Michigan Survey Research Center. From the 5,000 households we selected all low-income households that live in rented dwellings in metropolitan areas with populations greater than 50,000 and that live within 30 miles of the central busimess district. From this sample, households were removed if data were missing or if income/rent ratios indicated probable error in the measurement of either one or both variables.

\section{A. Regression Analysis as a Tool in Assessing the Impact of Laws}

Many factors other than the introduction of housing laws affect rent increases, and the presence of housing laws may be correlated with other variables which also influence housing expenditures. For example, habitability laws have been implemented nost frequently in the highly urbanized areas of the North, East, and North Central regions of the United States where lot values, construction costs, imcomes, and operating and mamtenance costs tend to be high. Thus the fact that states with habitability laws had higher rents than states without such laws, would not necessarily be attributable to the presence of such laws.

However, by the use of statistical multiple regression techniques, it is possible to partial out the effects of such extraneous variables and observe the effects of the independent variables of interest, habitability

82. For purposes of this study, "low-income tenants" were defined as households with 1968 incomes below the following levels:

Persons

Income per household
$\$ 2,359$
2,873
3,385
4,164
4,797
5,317
6,400
7,500

These figures represent 40 percent of the Bureau of Labor Statistic's low-income standard housing expenditure for a family of four in 1968. Bureau of Labor STATISTICS, Low-Income Standard Housing for a FamLy of Four IN 1968 at 33 (1968). Adjustments for family size follow the size differentials in U.S. BUREAU of THE CENSUS, Current Population Reports, Series P-60, No. 68, Poverty in the United States 1954-1968 at 11 (1969). In addition, no household was included if its average dollar income for the five year period exceeded $\$ 8,000$.

83. For a discussion of multiple regression techniques see WaNnacot \& WaNNACOT, ECQNOMETRICS 53-81 (1970). 
laws, upon the dependent variable, rents. The analysis proceeds by formulating a relationship between the rent paid by tenants and a number of independent (explanatory) variables. The independent variables include a set of extraneous variables which are hypothesized to have effects on the level of rent; to these variables are added other independent variables representing habitability laws. ${ }^{84}$ The statistical procedure then seeks to identify the individual effects of the various independent variables. The hypothesized relationship between rent and the various independent variables can be expressed in equation form as follows:

$$
\begin{aligned}
\text { RENT }= & \mathrm{B}_{0}+\mathrm{B}_{1} \text { (number of rooms) }+\mathrm{B}_{2} \text { (distance to center of } \\
& \text { the Standard Metropolitan Statistical Area (S.M.S.A.)) } \\
& +\mathrm{B}_{3} \text { (structure type) }+\mathrm{B}_{4} \text { (repair status) }+\mathrm{B}_{5} \text { (house- } \\
& \text { hold's average incoine) }+\mathrm{B}_{6} \text { (lot value) }+\mathrm{B}_{7} \text { (depreci- } \\
& \text { ation) }+\mathrm{B}_{8} \text { (S.M.S.A. income) }+\mathrm{B}_{9} \text { (construction cost) } \\
& +\mathrm{B}_{10} \text { (repair and deduct laws) }+\mathrm{B}_{11} \text { (rent withholding } \\
& \text { and retaliatory eviction laws) }+\mathrm{B}_{12} \text { (receivership laws). }
\end{aligned}
$$

Other independent variables inay be added to test alternative hypotheses.

The objective is to choose values for the $B$ coefficients so that for each household the result of the computation on the right-hand side is equal to the actual observed value for rent. Since there are many households and only one set of B's, this cannot be made to work out exactly for each observation. There are, however, statistical methods for the determination of B's which will cause the computed value on the right to be as close as possible, on average, to the observed value on the left. The value that the regression process computes for the coefficient of a particular habitability law is approximately the difference, on average, between the states that have habitability laws and those which do not. 85

The relationship we estimated incorporates the variables which are

84. Habitability laws are represented by zero-one "dummy" variables. If a specific habitability law is present, we assign a 1 , and if it is not, we assign a 0 .

Since we do not have enforcement data, we are forced to assume that once a law is in force, landlords and tenants are aware of its presence and react rationally to the resulting incentives or disincentives.

85. However, even after accounting for the variability associated with the major causal factors affecting rent, one can expect some unexplained variation. This variation may be caused by a wide variety of more or less random factors. The relationship between the difference apparently associated with an individual variable and the variation which seems to occur randomly is expressed in a statement of statistical significance. If the random variation is large relative to the variation that seems to be "caused" by a given variable, it is likely that the effect attributed to the variable also has occurred randomly. If, on the other hand, the random variation-of rents, in this case-is small compared to the variation attributable to, e.g., income, the statistical relationship between the household's income and the rent paid is likely to bo real, rather than randoin. If there is only a 10 percent (or 5 percent) chance that the observed relationship between income and rent could occur as a coincidence, then the income variable is said to be significant at a 90 percent (or 95 percent) level. 
most likely to affect rent payments. ${ }^{86}$ These variables can be divided into four categories. The first two are those which influence the aggregate demand and supply for housing and consequently affect the general level of rents within a city. The aggregate supply factors are represented by indices of construction and heating costs, ${ }^{87}$ the lot values of equivalent sites by S.M.S.A., ${ }^{88}$ and a depreciation variable. ${ }^{89}$ Demand factors are indicated by the average household income for renters in the S.M.S.A., ${ }^{30}$ and the average income for the household..$^{91}$ The third category is related to the characteristics of the individual dwelling unit: distance to the center of the city, the number of rooms in the dwelling umit, the state of repair, and the type of structure in which the dwelling is located. A final category of variables consists of a series of zero-one "dummy variables" which respectively indicate the absence or presence of various habitability laws in early 1972 in an S.M.S.A. They are repair and deduct, a combination of withholding and retaliatory eviction, and receivership. ${ }^{92}$ If enforced, they are likely to impose costs on landlords and, therefore, are expected to be positively correlated with rent.

\section{B. Results}

An ordimary least-squares regression of the hypothesized equation was estimated, relating rent (RTIL 2) to subsets of the various independent variables described in table 2 for 182 observations representing 50 S.M.S.A.'s. The results are given in table $3 .^{93}$

86. The value used for "rent payments" was the total contract rent plus payment for utilities. The cost of utilities was included so that values would be comparable regardless of whether utilities were included in the contract rent or paid separately.

87. AMERICAN APPraisal COMPANY, BoECKh BUILDING COST INDEX, NOVEMBerDeCEMBER, 1972, APARTMENT BUILdINg INCOME/EXPENSE ANALYSIS 14 (1972).

88. U.S. Department of Housing and Urban Development, Data for States and Selected areas on Characteristics of FHA Operations under Section 203, Table 18M (1972).

89. U.S. Department of Commerce, 1970 Census of Housing, Metropolttan Housing Characteristics, Final Report HC(2) (1972).

90. Id.

91. From the Michigan Survey. All other variables, except where noted, are from this source.

92. Retaliatory eviction laws were combined with rent withholding laws in a composite variable. (The withholding/retaliatory eviction variable is a dummy with $I$ indicating that both laws exist and 0 indicating otherwise.) This formulation of the three law variables is based on the following argument-repair and deduct remedies are not very costly to landlords and, therefore, furmish little imcentive to evict tenants. Protection from retaliatory eviction is, therefore, not important. Likewise, such protection probably plays a minor role in relation to receivership laws, since they seldom are tenant-initiated. However, because rent withholding laws tend to be costly and tenantinitiated, tenants require protection from retaliatory eviction. Therefore, in the empirical analysis withholding and retaliatory eviction laws are combined into one variable.

93. A copy of the computer print-out is on file in the offices of the California Law Review. 
Table 2

Variable Descriptors

\begin{tabular}{|c|c|c|}
\hline $\begin{array}{l}\text { Variable } \\
\text { Name } \\
\end{array}$ & Description & Source \\
\hline RTIL 2 & $\begin{array}{l}\text { Sum of annual household rent and utilities } \\
\text { paid in } 1972\end{array}$ & $\begin{array}{l}1972 \text { Michigan } \\
\text { Survey }\end{array}$ \\
\hline ROOM 2 & Number of rooms in a particular dwelling & $\begin{array}{l}1972 \text { Michigan } \\
\text { Survey }\end{array}$ \\
\hline DIST 2 & $\begin{array}{l}\text { Distance of housing structure to the center } \\
\text { of the SMSA }\end{array}$ & $\begin{array}{l}1972 \text { Michigan } \\
\text { Survey }\end{array}$ \\
\hline STRU 2 & Identifies structures of different types & $\begin{array}{l}1972 \text { Michigan } \\
\text { Survey }\end{array}$ \\
\hline REP 2 & Identifies dwellings in need of major repairs & $\begin{array}{l}1972 \text { Michigan } \\
\text { Survey }\end{array}$ \\
\hline AVGI & $\begin{array}{l}\text { Average household income for a 5-year } \\
\text { period, } 1968-72\end{array}$ & $\begin{array}{l}\text { 1968-72 Michi- } \\
\text { gan Survey }\end{array}$ \\
\hline LOT & $\begin{array}{l}\text { Average lot value of equivalent sites in } \\
\text { SMSA's }\end{array}$ & FHA 1972 \\
\hline DEPR & $\begin{array}{l}\text { Ratio of tenth percentile unit's rental price } \\
\text { to the median of housing unit's rental price }\end{array}$ & 1970 Census \\
\hline RENTY & Median SMSA household income for renters & 1970 Census \\
\hline CON COST & $\begin{array}{l}\text { Costs of construction for brick/coucrete } \\
\text { apartments across cities }\end{array}$ & $\begin{array}{l}1972 \text { Boeckh } \\
\text { Index }\end{array}$ \\
\hline HEAT & $\begin{array}{l}\text { Average annual heating cost per room for } \\
\text { rental units in an SMSA }\end{array}$ & $\begin{array}{l}1972 \text { Apartment } \\
\text { Building Income } \\
\text { Expense Analys }\end{array}$ \\
\hline REDUCT & $\begin{array}{l}\text { Identifies states with repair and deduct } \\
\text { housing laws }\end{array}$ & $\begin{array}{l}1972-\text { own re- } \\
\text { search of stat- } \\
\text { utes and cases }\end{array}$ \\
\hline RWHOLD & $\begin{array}{l}\text { Identifies states with both retaliatory } \\
\text { eviction and withholding laws }\end{array}$ & $\begin{array}{l}1972 \text { - own re- } \\
\text { search of stat- } \\
\text { utes and cases }\end{array}$ \\
\hline RECEIVE & Identifies states with receivership laws & $\begin{array}{l}1972 \text {-own re- } \\
\text { search of stat- } \\
\text { utes and cases }\end{array}$ \\
\hline
\end{tabular}

Table 3

Variables in the Equation ${ }^{94}$

(Dependable Variable: LRTIL)

\begin{tabular}{ll}
\multicolumn{2}{l}{ Variable } \\
\hline 1. & ROOM 2 \\
2. & DIST 2 \\
3. & STRU 2 \\
4. & REP 2 \\
5. & LAVGI
\end{tabular}

$$
\begin{array}{r}
\frac{\mathrm{B}}{0.08453} \\
-0.03027 \\
0.12764 \\
-0.12645 \\
0.37502
\end{array}
$$

\begin{tabular}{c} 
F-value \\
\hline $36.510^{*}$ \\
0.926 \\
$8.309^{*}$ \\
$10.077^{*}$ \\
$60.453^{*}$
\end{tabular}

94. The regression coefficients ( $B$ 's) can be interpreted in the following manner: 0.08453 (ROOM 2) - An additional room tends to add about $\$ 84.00$ to the annual rent paid by the household.

0.12764 (STRU 2)-If a dwelling is in a large apartment structure rather than a single umit, or a duplex (all of which tend to be poorly maintained 


$\begin{array}{rlrl}\text { 6. } & \text { LLOT } & 0.16987 & 4.633^{*} \\ 7 . & \text { LDEPR } & 0.00473 & 0.650 \\ \text { 8. } & \text { LRENTY } & 0.34884 & 2.311 \\ \text { 9. } & \text { LCONCOST } & 0.09320 & 0.247 \\ 10 . & \text { LHEAT } & -0.02440 & 0.172 \\ 11 . & \text { REDUCT } & 0.00195 & 0.001 \\ \text { 12. } & \text { RWHOLD } & 0.08290 & 2.021 \\ 13 . & \text { RECEIVE } & 0.12488 & 4.809 * \\ & \text { CONSTANT } & -1.55211 & \end{array}$

Sample Size $=182$

* Significant at the 95 percent level

$\mathrm{R}^{2}=.63$

F-statistic for equation $=22.03$

$\mathrm{L}$ before variable name denotes logarithmic form.

The estimated regression equation is statistically "highly significant," with an F-value of 22.0. It has, moreover, relatively good explanatory power, accounting for 63 percent of the variation in rents paid in 1972 by indigent tenants in our sample. ${ }^{95}$ The results indicate that in 1972, indigents paid statistically higher rents-approximately $\$ 125$ per year higher-in states which had receivership laws than in states which did not have such laws. ${ }^{96}$

However, while all of the habitability law variables indicate a positive relationship between presence of habitability laws and high rent, only one variable, receivership, is statistically significant. This result is consistent with our earher observation that of all of the variations of habitability laws, receivership laws are the most costly to landlords. While repair and deduct and withholding remedies are dependent upon tenant imitiative, the receivership remedy is tied to the greater resources of a governmental agency. In addition, receivership remedies are applied on a building-wide basis. Even those tenants who would not normally invoke a withholding remedy are forced to pay their rent into a courtcreated escrow, rather than to the landlords. Moreover, unlike rent withholding and repair and deduct remedies, the control and manage-

when used for low-cost housing), the annual rent, on the average, is about $\$ 128$ higher.

-0.12645 (REP 2)-If a dwelling requires major repairs the annual rent averages about $\$ 126$ less than the rent for dwellings in better repair.

The coefficients for other statistically significant variables (e.g., variables significant at the 95 percent level) can be interpreted in a similar manner.

95. All variables except heating cost (HEAT) have the expected sign. The annual heating cost variable has a very small coefficient and, more importantly, is statistically insignificant. Of the housing characteristics in our equation, the number of rooms in the dwelling, structure type, and repair status are all statistically significant at a 99 percent significance level. Average household income during 1968-73 for households in the study is also statistically significant, and median income for all renters in the S.M.S.A. has a positive coefficient, but is not significant. Lot value is also significant at a 95 percent level.

96. The average 1972 annual rent for the units in the sample was $\$ 1,082$. 
ment of the building is removed from the landlord under a receivership approach. The consequent loss of control over repairs may be especially costly to the landlord because the receiver is relatively unrestrained by profit considerations. Thus it would seem that the effects of receivership laws should be more pronounced than those of other kinds of habitability laws, primarily because receivership remedies are likely to impose greater costs on landlords.

\section{Analysis}

Two conclusions stand out from the empirical results. First, the regression equation we constructed is a relatively good one-it can explain a large percentage of the variation in rents paid by low-mcome tenants in the Umited States in 1972, and it does so with a relatively high degree of confidence. Second, given the strength of the explanatory power of the equation, we can say with a relatively high degree of confidence that in the early 1970's the presence or absence of receivership laws had a statistically significant effect on the rents paid by lowincome tenants. Thus, ceteris paribus, rents in states with receivership laws were, on the average, about 12 percent higher than in those without such laws. Clearly, these empirical results support neither Judge Wright's statement about the effects of housing codes, ${ }^{07}$ nor Professor Ackerman's formulation of the problem. ${ }^{08}$

The same confidence cannot be expressed in relation to repair and deduct and rent withholding remedies. A number of explanations may be offered to account for the lack of a strong relationship between the availability of the repair and deduct and rent withholding remedies and levels of rent. The most logical explanation, and the one most consistent with the sketchy empirical information which exists on the subject, is that repair and deduct and rent withholding remedies are not being used by tenants to any great extent. ${ }^{09}$ If these remedies are not widely used, no real costs would be imposed on landlords, and thus there would be no increased costs to be passed on to tenants.

97. See Robinson v. Diamond Housing Corp., 463 F.2d 853, 860 (D.C. Cir. 1972), quoted at text accompanying note 8 supra.

98. Ackerman, Slum Housing Markets, supra note 9 at 1102-04.

99. There is a complete lack of empirical data on the trial court level. Brian Robbins, staff attorney at the National Housing and Economic Development Law Project of the Earl Warren Legal Institute, School of Law, University of California at Berkeley, has toured approximately 16 states and held conferences with numerous local landlord-tenant attorneys. It is his impression that tenant-initiated code enforcement reinedies are rarely invoked by tenants. Mr. Robbins attributes the infrequent use of such remedies to the tenants' lack of information and a general reluctance on the part of courts to recognize the applicability of such remedies. Letter froin Brian Robbins to Joel Hirsch, May 13, 1975, on file in the offices of the California Law Review. 
If tenant-initiated code enforcement remedies are not widely used by tenants (or at least were not frequently used by tenants from 1968 to 1972 , the years included in this study), the question then arises as to the reasons for their lack of use. Housing and legal service agencies often poimt to the lack of information and resources on the part of poor tenants. If costs are indeed passed on to low-imcome tenants, as suggested by the experience with receivership laws, a greater availability of information and resources for indigent tenants may result in higher rents being charged. Thus, if legal service organizations increase the probability that tenants will invoke habitability laws, such organizations may hurt, rather than help, their chents, at least to the extent of indirectly giving inupetus to an increase in rent.

There is another possible explanation for the infrequent use of such remedies, however. Tenants may indeed know of the availability of such remedies and in addition perceive the potentially counterproductive consequences of invoking such remedies. Thus, the infrequent use of tenant-initiated code enforcement mechanisms may be a reflection of a foresighted perception of self-imterest. This explanation suffers from two potential defects. First, this explanation may be circular-that is, it uses the possibility of an increase in rent (the existence of which we seek to prove or disprove) to explain the non-existence of such increases. In addition, this explanation makes the assumption that low-income tenants perceive the likely consequences of invoking tenant remedies. This assumption may be questioned on the ground that in the short run the tenant who invokes legal remedies may not be the one who suffers the effects of his actions. Retaliatory eviction laws may temporarily insulate the initiating tenant from economic responsibility for his actions. However, on an aggregate level, all low-income tenants in the immediate housing market will suffer the counterproductive effects of the initiating tenant's actions.

Despite the existence of these theoretical flaws, the above explanation has an undemable intuitive appeal. Low-income tenants are undoubtedly deterred from exercising their rights when faced with the prospect of being forced, upon short notice, to find new accommodations in an extremely tight housing narket. The uncertainty of the law itself may restrain the exercise of tenant rights. In addition, there is probably an unstated recognition on the part of tenants that the law can provide little protection against a hostile landlord. Tenants are acutely aware that a landlord can make a tenant's life extremely unpleasant despite the formal existence of retaliatory eviction laws. The costs of resorting to the law to vindicate one's rights as a tenant may become so burdensome as to make continued occupancy unpleasant even if a tenant's right to possession is formally sanctioned by the law. 
A third explanation for the lack of relationship between tenantinitiated rensedies and rent increases concerns nethodology. The above results were derived from cross-section data of all low-income tenants. However, certain subclasses of tenants may feel the impact of habitability laws inore than others. Indeed, a more detailed analysis of elderly indigent tenants indicates that they are more severely affected than other low-income tenants by the additional costs associated with the introduction of habitability laws. For example, a regression analysis of a subsample of indigent tenants over 60 years old indicates that they paid significantly higher rents in 1972 in states which had habitability laws than in those states which did not. ${ }^{100}$ Holding constant the effects of income, lot value, repair status, and number of rooms, aged tenants in states with habitability laws were found on the average to be paying nearly $\$ 122$ more per year than their counterparts in states which did not have sucli laws. The average annual rent for the subsample was $\$ 819$ and the five explanatory variables were able to explain about 83 percent of the rent differentials.

It appears that aged tenants are particularly hard hit because they lack nobility. Between Marcl 1970 and Marcl 1971, 8.3 percent of the persons 65 and over changed their domicile, compared to 41 percent of the 20-24 year age group and 27.5 percent of the 25-34 year age group. These data suggest that despite their fixed incomes, aged tenants are less likely to move in the face of a decrease in services or an increase in rent. In turn, the relative inelasticity of demand in this sector of the low-income liousing market ineans that landlords will be relatively unhesitant to raise rents for the immobile elderly. On the other hand, landlords niay be inore reluctant to raise the rents of the more mobile class of younger tenants.

100. The study is reported in W. Hirsch, How to Hurt Aged Tenants Without Even Trying, 121 CONGRESSTONAL RECORD 1080 (1975).

The following multiple regression equation was estimated:

RENT $=61.8+122.0$ Law +0.20 Income + 0.04 Lot Value

$(3.0) \quad(40.4) \quad(10.9)$
+45.6 Room Number - 194.9 Repair Status
(6.5)

Because of the small sample size, a composite "Law" variable was used; the variable was assigned a value of 1 if the state had any one of the major habitability laws, and 0 otherwise. The "Repair" variable was assigned a value of 1 if the dwelling was in need of major repairs, and 0 otherwise. The regression equation had a $R^{2}$ value of 0.83 , which is highly significant, as are the F-statistics (numbers in parentheses indicate the F-statistics for the individual variables). The F-statistic for the entire equation is 17.1. The critical F-statistics for a sample size of 23 are as follows:

$\begin{array}{cc}\text { Significance level } & \text { F-statistic } \\ 0.90 & 3.0 \\ 0.95 & 4.4 \\ 0.975 & 6.0\end{array}$




\section{The Second Prong: Are Tenant Benefits Greater Than the Increases in Rent?}

The fact that tenants may be forced to pay imcreased rents in the presence of habitability laws does not necessarily mean that tenants are worse off. The benefits tenants receive by virtue of such laws may exceed the increments of rent increase. Thus the question remains: to what extent are the rent increases incurred by indigent tenants compensated by increases in their overall welfare?

Some might argue on a priori grounds that, except under the most unusual circumstances, benefits froin habitability laws are unlikely to exceed costs imposed on indigent tenants. If tenants wanted better housing and were willing and able to pay for it, they would have rearranged their budgets, made sacrifices, and, conceivably, secured standard housing even without the help of habitability laws. Obviously, not all poor tenants have chosen or are able to choose this option, as is evidenced by the fact that many low-income tenants still reside in dilapidated dwellings. This argument leads to the conclusion that indigent tenants spend as much on housing as they consider to be in their best interests. ${ }^{101}$

There are, however, a number of counter-arguments which undercut the validity of the above argument. First, major transaction costs make impractical the modification of existing landlord-tenant relationships by voluntary action. For example, im many cases tenant and landlord belong to different ethnic or socio-economic groups, making comnunication difficult and otherwise complicating transactions. In addition, in many areas, uniform leases are widely used, and deviation from these standard forms may impose substantial costs on both landlord and tenant. Not only would specialized forms be required, but the landlord's actual and perceived habilities may increase, thereby creating additional costs that might be passed on to tenants.

A second possibility is that even in the absence of a habitability law, landlords provide the benefits that are required by law, but do so in a discriminatory fashion. For example, landlords may find that while occupancy by any individual will cover operating costs, there are occasionally tenants who, by virtue of their immobility, will continue to he in the dwelling and pay essentially the same rent even when landlords sharply curtail services. These tenants will make it possible for the landlord to reduce operating costs without a corresponding downward

101. Again, the assumption is that because of habitability laws, the supply of low quality housing may shrink (i.e., less housing is available at any given price), resulting in rent increases. Consequently, indigent tenants will have to pay more for the same quality housing they did before habitability laws were established. 
rent adjustment and therefore make larger profits. This argument corresponds conceptually to the application of a price discrimination model which is commonly found in the economic literature on industrial organization. ${ }^{102}$ The landlord is in a sense a monopolist. Since the tenant has moved his possessions into a dwelling and has a psychological attachment to this location, he would incur heavy transaction costs were he to move. Under such conditions, the landlord can increase profits by charging different prices to customers with different demands-e.g., high rents or low services for those whose alternative opportunities are limited. ${ }^{103}$ In many circumstances landlords are unable to charge different rents-e.g., if all units are identical-and so, will accomplish this price discrimination by altering the level of service provided.

A third possible explanation for the failure of voluntary action is that both tenants and landlords may be unsure of the lease provisions, what provisions can be added to the lease, or the costs of enforcement. A tenant may simply observe that most other renters receive a certain package of services and assume that it is a part of the landlord's obligations. If the service is not obtained, he may regard it as a failure of the landlord to honor the existing contract rather than his own failure to contract for the desired level of services. Even when the tenant believes there is an implied obligation on the part of the landlord, he may think that the costs of enforcement are too high, and not seek to have the contract enforced. Similarly, the tenant might be willing to pay some additional amount for assurances of better service, but he may feel that judicial enforcement of such a contract is either unlikely or expensive. Habitability laws may be interpreted as an attempt to reduce the costs of enforcing rental contracts-i.e., reducing one important class of transaction costs. Thus there are conflicting theories on the likelihood that the benefits of habitability laws will exceed their costs. There remains, therefore, an additional empirical investigation to be conducted relative to the effect of habitability laws.

Recent evidence, however, suggests that the benefits of such habitability laws may not exceed their costs. New York's experience with public rent withliolding is an illustrative example. In 1962, New York passed the Spiegel Act ${ }^{104}$ in an effort to prevent state funds, int the form of housing allowances for welfare recipients, from going to landlords who own residential buildings which flagrantly violate housing codes.

102. See, e.g., Hilton, The British Truck System in the Nineteenth Century, 65 J. of Polrt. ECON. 237-56 (1957); Kessel, Price Discrimination in Medicine, 1 J. Law \& ECON. 20-53 (1957).

103. The price discrimination theory is consistent with the empirical finding that the law has its greatest effect on households with reduccd mobility. See text accompanying note 102 supra.

104. N.Y. Social Welfare LaW \$ 143-b (McKinney 1966). 
The Act allowed the state welfare department to withhold housing allowances from landlords until the code violations were corrected. When the Spiegel Act was passed it was widely hailed as an important weapon in the arsenal of housing code enforcement inechanisms. ${ }^{105}$ The number of rent withholding cases brought under the Act rapidly increased after its passage in 1962 and reached its peak in 1966. After 1969, the law was seldoin invoked, most likely because of a realization that such a withholding law worked to the detriment of imdigent tenants. ${ }^{106}$

The demise of the Spiegel Act, however, may also be attributable to the particular form of the law. Because this law only affected structures whose occupants included welfare recipients, landlords could avoid the law by refusing to rent to welfare recipients. In addition, rent control laws in effect during these years precluded the landlord from passing on

105. See Simmons, Passion and Prudence: Rent Withholding Under New York's Spiegel Law, 15 BUF. L. Rev. 572 (1965).

106. Welfare officials were aware of the counterproductive results of invoking the Spiegel Act. One official observed:

As the effectiveness of the defense provided by the statute... became known, landlords knowing or suspecting that they were in violation of the ... codes ... . would not rent to welfare recipients since they knew that we would defend them in court. . . . Thus developed an ironic situation, to wit: The more successful we were in using section 143-b, the availability of housing in this community shrunk proportionately, making our housing problem ... more acute.

Simmons, Passion and Prudence: Rent Withlolding Under New York's Spiegel Law, 15 Buf. L. Rev. 572, 587 n.72 (1965). See also I. LoWRY, J. GuERon, \& K. EISENSTADT, Welfare Housing IN New York CTTY 25 (1972).

This evidence is only suggestive. A regression analysis should be condncted to verify the conclusion that the Spiegel Act produced counterproductive results and that this factor was indeed the reason for its nonuse in recent years.

The pattern of usage of the Spiegel Act is shown in the following table:

RENT WTHHHELD UNDER NEW YORK'S SPIEGEL ACT AUGUST 1, 1962 to DECEMBER 31, 1969

Judgment for Landlord

\begin{tabular}{|c|c|c|c|c|c|c|c|c|c|}
\hline 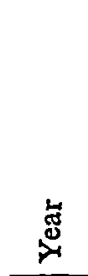 & 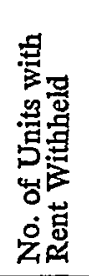 & 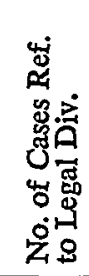 & 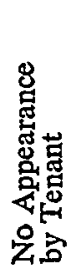 & 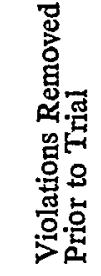 & 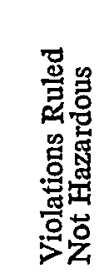 & 帒 & 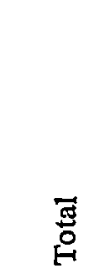 & & 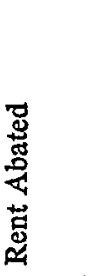 \\
\hline $\begin{array}{l}1962 \\
1963 \\
1964 \\
1965 \\
1966 \\
1967 \\
1968 \\
1969\end{array}$ & $\begin{array}{l}1514 \\
2851 \\
5223 \\
3418 \\
6006 \\
2752 \\
2501 \\
47\end{array}$ & $\begin{array}{r}210 \\
1773 \\
2659 \\
2487 \\
2986 \\
1571 \\
1847 \\
273\end{array}$ & $\begin{array}{r}0 \\
0 \\
0 \\
0 \\
23 \\
135 \\
158 \\
23\end{array}$ & $\begin{array}{r}0 \\
0 \\
0 \\
0 \\
0 \\
88 \\
158 \\
22\end{array}$ & $\begin{array}{r}0 \\
0 \\
0 \\
0 \\
0 \\
957 \\
1252 \\
113\end{array}$ & $\begin{array}{r}0 \\
0 \\
0 \\
0 \\
0 \\
7 \\
10 \\
3\end{array}$ & $\begin{array}{r}155 \\
1448 \\
2316 \\
1991 \\
2424 \\
1193 \\
1533 \\
161\end{array}$ & $\begin{array}{r}0 \\
0 \\
0 \\
0 \\
0 \\
0 \\
\$ 51,895.80 \text { in } 338 \\
\$ 43,532.02 \text { im } 475 \\
\$ 10,499.22 \text { im } 42\end{array}$ & $\begin{array}{l}0 \\
\text { cases } \\
\text { cases } \\
\text { cases }\end{array}$ \\
\hline
\end{tabular}


the costs of repairs to tenants. Thus, the supply response to the Spiegel Act was most likely much larger than one would expect in relation to habitability laws in general.

\section{IV}

\section{Policy IMPlications AND CoNClusions}

Habitability laws were designed to ensure indigent tenants "facilities in a condition which render the property liveable." ${ }^{107}$ In formulating remedies to achieve this goal, courts and legislatures made the determination that sanctions were most appropriately directed at landlords rather than tenants. Judge Cardozo, then sitting in New York, commented that "unless repairs in the rooms of the poor were made by the landlord, they would not be made by anyone."108 We have seen, however, that attempts to solve the housing quality problem with legal sanctions alone will not be entirely successful. Rents tend to increase, and only under certain circumstances can habitability laws be expected to provide indigent tenants with housing quality benefits which exceed these rent increases. Indigent tenants may be worse off than they were before habitability laws were introduced.

Habitability laws, however, have an undemiable political appeal. As Posner has shrewdly observed: "To deal with the problem of substandard housing by legal sanction has the . . . attraction of . . . seeming to enable a principal manifestation of poverty to be eliminated without any expenditure by the government." 100 If legislators are in fact committed to improving the housing of poor tenants, it would seem that they must

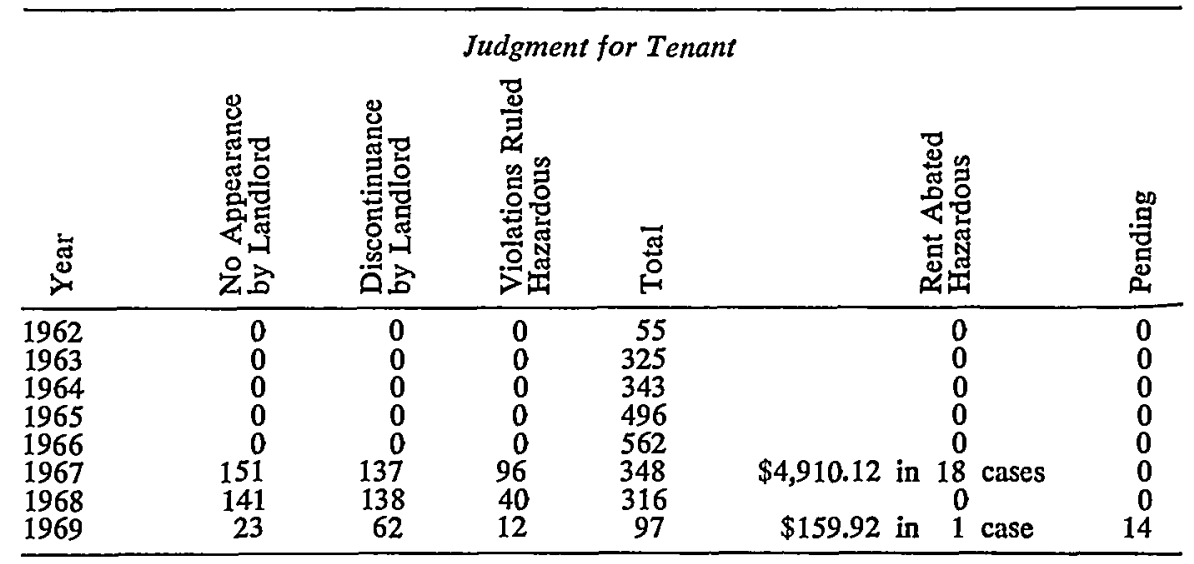

**Court order to deposit rent with clerk, payable to landlord upon proof of removal of violations, pursuant to section 755 of Real Property Action and Proceeding Law.

Source: New York Welfare Department.

107. Marini v. Ireland, 56 N.J. 136, 144, 265 A.2d 526, 532 (1970).

108. Altz v. Leiberson, 233 N.Y. 16, 19, 134 N.E. 703, 704 (1922).

109. R. Posner, Economic ANALysis of THE LAW 258 (1973). 
supplement habitability laws and their enforcement with programs providing increased purchasing power for the poor.

A number of policies, often referred to as demand or income policies, are available to improve the purchasing power of poor tenants. To the extent that tenants live under substandard housing conditions because of their low incomes, welfare payments to supplement their incomes might be considered. The income elasticity of the demand for housing service provides an index of the likely effectiveness of such policies. There are empirical indications that this income elasticity is low, i.e., somewhere between 0.8 and 1.0, and that therefore housing gains from general welfare payments will be relatively small. ${ }^{110}$ Even if low-income rentals had a high income elasticity, policies designed to enhance the incomes of low-income groups and give thein better housing face major obstacles. If mcome increases are substantial and sudden, in the absence of an excess supply of middle-quality housing, sharp rent increases could be expected, because not enough housing stock could be profitably down-filtered. Furthermore, members of minority groups often would be prevented from obtaining better housing at reasonable prices because of discrimination.

A second, more selective, income policy appears more promising. Rent supplements or rent certificates imght be used to raise the real income of low-incoine individuals in a manner which would efficiently increase their purchasing power for housing. Unlike a general imcome supplement, rent supplements are earmarked for housing and, therefore, would be used for that purpose regardless of the income elasticity of the demand for housing. The question remains, however, whether sharp demand increases would lead to large rent increases.

Federal policy has changed on whether payments should be made directly to the tenant or the landlord. A sinall-scale rent supplement program was enacted under the Johnson Administration in 1965. ${ }^{111}$ Under that program payments were inade to landlords. In 1970 Congress passed a new rent suppleinent prograin under which housing allowances are made directly to eligible tenants who select rental housing of their own choosing. ${ }^{112}$ Eligibility criteria relate to mcome levels. Those

110. F. deLeeuw, The Demand for Housing: A Review of Cross-Section Evidence, 53 Rev. OF ECON. StatTSTICS 7 (1971).

111. The 1965 program required eligible families to pay 25 percent of their incomes for rent, while the federal government paid directly to the landlord the difference between the rent and the tenant's payments. U.S. Housing and Urban Development Act of 1965, Pub. L. No. 89-117, § 23, 79 Stat. 451. For an appraisal of programs under this act, see H. Aaron, Shelter and SubSidies: Who Benteits From Federal HousING PoLICIEs? 133-36 (1972).

112. For a detailed description, see U.S. Department of Housnng AND URBan Development, Office of Policy Development and Research, First ANNual Report 
who are eligible are paid the difference between the rental price of standard housing and 25 percent of their incomes. The advantages of this approach are the strict earmarking features and the fact that tenants have an opportunity to move from their present residences.

Rather than directly providing funds to increase the purchasing power of indigent tenants, another possibility would be to reduce the costs to landlords. But the question remains as to whether landlords would in fact pass on the cost reduction to tenants in the form of lower rents. Various approaches, often referred to as cost and supply policies, could be adopted to enhance the probability that such savings would be passed on. These policies entail reducing costs of housing services, or increasing the supply of improved housing. Cost reducing policies include steps toward cheaper and more readily available credit, lower land cost, lower construction cost, and tax policies designed to reduce the tax burdens of investors in housing and of housing occupants. For example, sections 235 and 236 of the Housing Act of 1968 provide for federal subsidies that, at a maximum, reduce the interest cost to the equivalent of a one percent mortgage. ${ }^{113}$ Tenants pay rents equal to 25 percent of income, and the owners make mortgage payments equal to 20 percent of incoine. Federal subsidies make up the difference between the anounts required for the actual inortgage on the new housing and the rents so established.

Finally, the supply of improved housing could be increased either through public construction or rehabilitation. Either method, however, would improve the housing conditions of poor tenants only if rent subsidies are also provided, so that both supply and income forces would be at work.

A major difference among the various demand and supply policy instruments discussed above is the rental housing supply response of investors and landlords. For example, the purpose of earmarked housing subsidies is to enable low-income tenants to purchase a larger quantity of housing services without decreasing their consumption of other goods and services. Froin a housing perspective, an instrument would be efficient if it were to increase the quantity of housing services consumed per dollar of housing subsidy. Maximun efficiency would be attained if housing expenditures increased by the full amount of the subsidy, with no price increase per unit of housing service. Until recently no definitive empirical evidence existed concerning the differential supply impact of

of the Experimental Housing Allowance Program, May 1973. Section 501 of the Housing Act of 1970, 12 U.S.C. \& 1701z-2 (1970), and Section 504, 12 U.S.C. \& 1701z3 (1970) direct the Department of Housing and Urban Development to establish an experiment to demonstrate the feasibility of a housing allowance program.

113. 12 U.S.C. $\S \S 1715 z, 1715 z-1$ (1970). 
different instruments. However, under sections 501 and 504 of the Housing Act of 1970, large scale supply experiments in Green Bay, Wisconsin, and South Bend, Indiana, are presently in progress. ${ }^{114}$

\section{CONCLUSION}

A major modification of the traditional landlord-tenant relationship came with the introduction of municipal housing codes. These codes placed ultimate responsibility for the condition of buildings upon their owners. The fact remains, however, that housing codes are not vigorously enforced. One possible reason for this lack of vigorous code enforcement is the fear on the part of policymakers that housing code enforcement may not be helpful to low-incoine tenants. Courts and legislatures have responded to the failure of government-initiated housing code enforceinent to ameliorate the housing crisis by decentralizing decisionmaking, providing for tenant-initiated code enforcennent.

With the aid of econounic theory, we have shown that given certain housing market conditions, the increased costs associated with habitability laws must, to some extent, be passed on. On an empirical basis, we found the presence of receivership laws to be significantly associated with higher rents. But the presence of repair and deduct and rent withholding remedies were not significantly related to rent levels. It was hypothesized that the lack of a statistically significant relationship between rent levels and these two remedies was due to the non-use of these tenant remedies. Alternatively, it was suggested that the costs associated with habitability laws may be passed on to some tenants more than others. For example, a statistically significant relationship between the rent level and the presence of habitability laws was found for the subcategory of elderly low-income tenants.

The question still remains, however, whether the rent increases associated with habitability laws will be offset by commensurate benefits accruing to tenants. This question was not answered herein. However, what sketchy evidence exists on this issue indicates that habitability laws are unlikely to effect a redistribution of wealth in favor of indigent tenants. ${ }^{115}$ Landlords alone cannot be expected to finance the achievement of this country's goal of a "decent home and suitable hiv-

114. Rand Corporation, First Annual Report of the Housing Assistance SUPPLY EXPERIMENT (1974).

115. After this Article went to the printer, the authors completed their research on this question. Their results will appear in G. INGRAM, The Economics of RESIDENTIAL LOCATION AND URBAN HousING MARKETS (1976). Specifically, this empirical analysis indicates that the costs imposed by receivership laws in terms of increased rents may outweigh the benefits accruing to indigent tenants. The results in relation to repair and deduct and rent withholding laws were not statistically significant. 
ing environment for every American family." In addition, retaliatory eviction laws cannot permanently insulate tenants from the economic effects of exercising their rights. Thus, unless some supplemental action is taken by federal or state government, low-income tenants inay be worse off in some ways with habitability laws than they would be without such laws.

In one sense, however, the extension of tenant rights in the form of tenant-initiated code enforcement inay constitute the ultimate compromise between two essentially irreconcilable forces: the desire to assure every tenant a decent living environment and the fact that such assurances impose costs on landlords which will often be passed on to tenants. By decentralizing decisionmaking to the class of people most likely to suffer the adverse effects of code enforcement, a basic restraint mechanisin has been built into the tenant-initiated code enforcement system. If tenants recognize the adverse effects of the exercise of their rights, they are less likely to exercise their rights and enforce housing codes. Consequently, the counterproductive effects of code enforcement (as well as code enforcernent itself) may be mininized. Such a conclusion is supported by our results. Increased rents were highly correlated with the presence of receivership laws (primarily a government-initiated remedy), whereas there was no such correlation in relation to the tenant-initiated remedies of repair and deduct and rent withholding.

Thus the results of our analysis should not be taken to mean that habitability laws are indefensible mistakes. In relation to warranty of habitability laws, the long overdue rejection of ancient property law notions and the adoption of contract principles as the governing law of leases signals a new, hopefully more rational, era in landlord-tenant relations. The point of this Article is that before value judgments become crystallized into legal doctrine and statutes, the various ramifications should be assessed and alternative means to vindicate the same operative values should be explored. It is in this area that the kind of economic and statistical analysis presented above may be of some value.

\section{APPENDIX \\ HABITABIIITY LAWS}

The final compilation of habitability laws is listed below. It is followed by a listing of related laws which did not fully meet the operational definitions of specific categories of habitability laws and which were excluded from the statistical analysis on that basis.

The following statutes and case authorities were included in the law file for the regression analysis:

(a) Repair and deduct laws were operationally defined as laws which allow tenants upon their own initiative to apply a portion of their rents solely for the purpose 
of repairing defects which render the premises uninhabitable after the landlord has been given reasonable notice and failed to take action. The following jurisdictions had such laws during the years 1968 to 1971: California-Car. Crv. CoDE $\$ \S 1941-42$ (West 1954); Georgia-Doughterty v. Taylor and Norton Co., 5 Ga. App. 773, 63 S.E. 928 (1909); Louisiana-LA. CTv. CoDE. art. 2694 (1952); Montana-Rev. Code MoNr. ANN. \& 42-202 (1961); New Jersey-Marini v. Ireland, 56 N.J. 130, 265 A.2d 527 (1970), North Dakota-N.D. CeNT. CODE \& 47-16-13 (1960); Oklahoma-OKIA. STAT. ANN. tit. 41, 32 (1954); South Dakota-S.D. CoMP. LAws § 43-32-9 (1967); Virginia -VA. CODE ANN. \& 32-64 (1973) (toilet facilities only).

(b) Withholding laws were operationally defined as laws which allow a tenant to inaintain possession and pay no rent (or a reduced proportion of rent) in response to the landlord's failure to unaintain the premises in an inhabitable condition. The following jurisdictions possessed such laws during the years 1968 to 1971: Connecticut-CoNN. Gen. StaT. ANN. \$\$47-24, 19.371 (1969 and Supp. 1975); District of Columbia-Javins v. First Nat'1 Realty Corp., 428 F.2d 1071 (D.C. Cir.), cert. denied, 400 U.S. 925 (1970); Iolva-Iowa CODE ANN. \$ 413.106 (1949); Maine-ME. Rev. Stat. ANN. tit. 14, § 6021 (Supp. 1974-75); Massachusetts-Mass. GEN. LAws ANN. ch. 239, § 8A (Supp. 1972); Missouri-ANN. Mo. STAT. $\$ 441.570$ (Supp. 1975) (requiring deposit of rent with clerk of the court); New Hampshire-Kline v. Burns, 111 N.H. 87, 276 A.2d 248 (Sup. Ct. 1971); New Jersey-N.J. STAT. ANN. tit. 2A, \& 2A:42-92 (Supp. 1975-76) (escrow remedy); New York-N.Y. Real Prop. ACr aNd Proc. LAw \& 755(2) (McKinney 1963); Pennsylvania-Pa. Stat. ANN. tit. 35, \$ 1700-1 (Supp. 1974-75); Wisconsin-Pines v. Perssion, 14 Wis. 2d 590, 111 N.W.2d 409 (1970); but cf. Posnanski v. Hood, 46 Wis. 2d 172, 174 N.W.2d 258 (1970). In Maryland, two local jurisdictions have rent withholding laws: Baltimore CTTY, MD., PuBlic LoCal Laws \$§ 9-9, -14.1 (1971); MONTGOMERY COUNTY, MD., CODE, Fair Landlord-Tenant Relations, chs. 93A et seq. (1972).

(c) Public rent withholding laws (included in the "withholding" category) were operationally defined as withholding laws, as defined above, which provide that rent payments shall be withheld by governmental agencies. The following jurisdictions possessed such laws during the years 1968 to 1971: Illinois-ILL. ANN. STaT. ch. 23, \& 11-23 (Sinith-Hurd Supp. 1975); Michigan-Mrch. Comp. LAws ANN. \& 400.14(c) (Supp. 1975-76); New York-N.Y. Soc. Welfare LaW \& 143-b (McKinney 1966) (Spiegel Act).

(d) Receivership laws were operationally defined as laws which allow a third party to take control of and manage a building containing substantial housing code violations and provide that the receiver is to collect the rent and apply it to correcting the defects. The following jurisdictions possessed such laws during the years 1968 to 1971: Connecticut-Conn. GEN. STAT. ANN. \$ 19-347b (1969); lllinois-Ill. ANN. STaT. ch. 24, art. 11-31-2 (Sinith-Hurd Supp. 1974); Massachusetts-MASs. GEN. LAws ANN. ch. 111 , §§ 127H et seq. (Supp. 1975); Michigan-Mrch. CoMp. Laws ANN. $\$ 125.535$ (Supp. 1975-76); Missouri-ANN. Mo. Stat. \$ 441.570 (Vernon Supp. 1975); New Jersey-N.J. Stat. ANn. tit. 2A, \& 2A:42-85 et seq. (Supp. 1975-76). See also N.J. STat. ANN. tit. 40, \& 40:48-2.12(h) (1967); New York-N.Y. Multr. DwELling LAW \$ 309 (5) (McKinney 1974); N.Y. Real Prop. Act and Proc. LaW $\$ \$ 769$ et seq. (McKinney Supp. 1974-75); Rhode Island-GEN. LAws OF R.I. \$\$ 45-24.2-11, 45-24.3-19 (1971 and Supp. 1974); Wisconsin-Wisc. STAT. ANN. $\$ 280.22$ (Supp. 1974-75).

(e) Retaliatory eviction laws were operationally defined as laws which prevent landlords from either evicting or raising the rent of tenants who have complained to governmental authorities or exercised their tenant rights regarding housing code violations. The following jurisdictions possessed such laws during the years 1968 to 1971: California-CaL. Crv. CODE $\$ 1942.5$ (West Supp. 1975); Schweiger v. Superior Court, 3 Cal. 3d 507, 476 P.2d 97, 90 Cal. Rptr. 729 (1970); Connecticut-CoNN. GEN. STAT. ANN. tit. 19, \& 19-375a (Supp. 1975); Delaware-DEL. CODE ANN. tit. 25, § 5516 (1975); District of Columbia-D.C. Housing REGS. $\S \S 2910$ et seq. (1970); Edwards v. Habib, 397 F.2d 687 (D.C. Cir. 1968), cert. denied, 393 U.S. 1016 (1969); Illinois -ILl. ANN. STAT. ch. 80, § 71 (Sinith-Hurd 1966); Maine-ME. REv. Stat. ANN. tit. 
14, § 6001 (1974); Massachusetts-Mass. GEN. LAws ANN. ch. 186, § 18 (Supp. 1975); Minnesota-Minn. STat. ANN., \& 566.03 (Supp. 1975-76); New Jersey-N.J. Stat. ANN. tit. 2A, § 2A:42-10.10 (Supp. 1975-76); New York-N.Y. Unconsol. LAws \$§ 8590, 8609 (McKinney 1974 and Supp. 1974); Pennsylvania-PA. Stat. ANN. tit. 35, § 1700-1 (Supp. 1974-75); Rhode Island-R.I. GEN. LAws ANN. ch. 20, § 34-20-10 (1970); Wisconsin-Dickhut v. Norton, 45 Wis. 2d 389, 173 N.W.2d 297 (1970).

The following statutes and case authorities were deleted from the law file because they were enacted or decided during 1972 and thus their effects on rent could not bo determined from the Michigan Survey Tape:

(a) Repair and deduct: Delaware-Dex. CoDn ANN. tit. 25, \& 5306 (1975); Hawaii-HAwaIr REv. StAT. tit. 28, § 521-64 (Supp. 1974); Massachusetts-MASS. GeN. LAws ANN. ch. 111, \& 127L (Supp. 1975).

(b) Withholding: California-Hinson v. Delis, 26 Cal. App. 3d 62, 202 Cal. Rptr. 661 (1st Dist. 1972); Delaware-DeL. Cope ANN. tit. 25, § 5307 (1975); Illinois -Jack Spring, Inc. v. Little, 50 III. 2d 351, 280 N.E.2d 208 (1972); Michigan-MrcH. Comp. Laws Ann. $\$ 554.139$ (Supp. 1975-76) and Rome v. Walker, 38 Mich. App. 458, 196 N.W.2d 850 (Mich. Ct. App. 1972).

(c) Receivership: Delaware-DeL. CoDe ArN. tit. 25, §§ 5901 et seq. (1975).

(d) Retaliatory eviction: Hawaii-HAwAII REv. STAT. tit. 28, § 521-74 (Supp. 1974); Michigan-Mich. Comp. Laws ANN. § 600.5720 (Supp. 1975-76).

The following possibly relevant laws were deleted from the law file because they did not fully meet our operational definitions of the specific categories of laws:

(a) Repair and deduct: Illinois-Ill. ANss. STst. ch. 80, \& 62 (Smith-Hurd Supp. 1972) (allows a teuant to pay utility fees when the landlord fails to); MichiganMrCH. COMP. LAWS ANN. \& 125.534 (Supp. 1974-75) (rent application allowed after court order); New York-N.Y. ReAL PRop. LaW \& 235-a (McKinney Supp. 1973) (allows tenant to pay utility company to prevent termination of service when the landlord refuses to pay).

(b) Withholding:

The following laws were excluded because they relieved tenants of the duty to pay rent only upon the destruction of the premises and/or did not specifically allow rent withholding: Arizona-ARIz. REv. StaT. ANN. $\$ 33-343$ (1956); California-CaL. Crv. CODE $\$ 1932$ (2) (West 1954); Connecticut-Cons. GEN. STAT. ANN. \& 47-24 (1949); Hawä̈-HawaII Rev. STAT. \$ 521-65 (Supp. 1975); Lemle v. Breeden, 51 Hawaii 426, 462 P.2d 470 (1969) (furnished dwellings; possession was not at issue); Lund v. MacArthur, 51 Hawaii 473, 462 P.2d 482 (1969) (unfurnished dwellings; possession was not at issue); Kentucky-Ky. Rev. Stat. ANN. $\$ 383.170$ (1972); Louisiana-LA. Civ. CODE ANN. art. 2697 (West 1952); Maryland-MD. ANN. CoDe art. 21, § 8-208 (1973); Michigan-Mich. Comp. Laws ANn. \$554.201 (1967); Minnesota-Minn, Stat. AnN. $\S 504.05$ (1947); Mississippi-Miss. Code ANN. § 898 (1957); Montana-Mont. Rev. Code Ann. \$ 42-108 (1964); New Jersey-N.J. Rev. STAT. \$ 46:87 (1940) (total destruction); $\$ 46: 86$ (1940) (obligation to pay rent suspended in partial destruction of premises); New York-N.Y. REAL PROP. LAW \& 227 (McKinney 1968); North Carolina -N.C. GeN. STAT. \$ 42-12 (1966) (if repairs would cost more than one year's rent); North Dakota-N.D. CENT. CoDe \$ 47-16-17 (1960); Ohio-Ohro Rev. CoDe ANN. § 5301.11 (Page 1970); Rhode Island-R.I. GEN. LAws ANN. § 34-18-7 (1969); South Dakota-S.D. Comp. LAws ANN. \& 43-32-19 (1967); Tennessee-TENN. CoDE ANN. \& 64-702 (1955); Virginia-VA. CODE ANN. $\$ 55-226$ (1969) (rent abated until building repaired; no termination of lease); West Virginia-W.VA. CODE ANN. $§ 37-6-28$ (1966) (rent abated while landlord repairs; if not repaired within a reasonable time tenant may terminate lease); Wisconsin-Wisc. Stat. ANN. \$ 704.07(4) (Special Pamphlet 1972) (rent abated while landlord repairs; if not repaired withim a reasonable time tenant may terminate lease).

The following laws were excluded because they authorize rent abatemont only for overcrowding: California-CaL. Crv. CODE $\S 1950$ (West 1954); Montana-Mont. Rev. Codes ANn. § 42-210 (1961); North Dakota-N.D. CENT. CODE $\S 47-16-26$ 
(1960); Oklahoma-OkLA. StaT. ANN. tit. 41, § 39 (1954); South Dakota-S.D. CoMP. LAws ANN. § 43-32-7 (1967). See also Irl. ANN. STat. ch. 24, § 11-31.1-12-1 (SmithHurd Supp. 1975-76); ch. 34, \& 423.1 (Smith-Hurd Supp. 1975-76) (damages for overcrowding).

(c) Receivership: Pennsylvania-PA. STaT. ANN. tit. 35, \& 1700-1 (Supp. 197475) (no specific provision for the collection or application of rent).

(d) Retaliatory eviction: Mllinois-ILL. ANN. STat. ch. 80, § 71 (Smith-Hurd Supp. 1974) (only a general statement of policy). 